\title{
Revisiting Conditional Accounting Conservatism in State-controlled Firms
}

\begin{abstract}
This study explores the demand for conditional accounting conservatism from equity shareholders in state-controlled firms. An investigation of state-controlled firms listed on Hong Kong Stock Exchange from 1997 to 2013 shows that the extent of conditional conservatism in state-controlled firms increases when the leverage ratio decreases. It is also found that the high control rights held by the government in state-controlled firms are associated with high conditional conservatism. In addition, further analyses document an offsetting effect between high control rights and firm leverage; a reinforcing effect between high control rights and year of incorporation after 1992; and a substituting effect between high control rights and dividend payments. These findings suggest that the demand from equity shareholders, in addition to the debt demand, can be an important determinant of conditional conservatism and examination of these differing sources of demand can enhance the understanding on accounting conservatism in state-controlled firms.
\end{abstract}

JEL Classification: G30, G32, M41

Keywords: Conditional accounting conservatism; Equity demand; leverage; high control; Statecontrolled firms. 


\section{Introduction}

The existing literature documents that Chinese state-owned firms do not have significant levels of conditional accounting conservatism [1] (conditional conservatism hereafter) primarily due to the low demand for conservatism from the debt or bank loan market (see Chen et al., 2010). If other determinants of conditional conservatism such as litigation, regulation or tax (see Watts, 2003; Garcia Lara et al., 2009) are assumed constant, the contracting determinant encompasses more than debt contracting. Little research is conducted on the conditional conservatism in Chinese state-controlled firms with no debt. This study attempts to explore additional dimensions of contracting determinant that could induce conditional conservatism in state-controlled firms, specifically examining the equity demand for conditional conservatism [2].

Along with the debt market demand for conditional conservatism, equity investors can demand accounting conservatism because it allows shareholders to mitigate managerial motivations of opportunistic activities such as expropriation and/or poor project selection (Watts, 2003). Investigating a subsample of US firms with zero leverage, Louis and Urcan (2015) find these firms also exhibit conditional conservatism. They attribute this result to the demand for conditional conservatism from equity investors and suggest that shareholders demand accounting conservatism to mitigate agency conflicts between shareholders and managers.

The investor attraction perspective is another dimension of the equity-market demand for conditional conservatism (Hirshleifer and Teoh, 2009). This view argues that individuals process gains and losses differently (Dickhaut et al., 2010), and the relative disappointment from losses exceeds the benefits of gains. Therefore, investors would demand for conditional conservatism because conditional conservatism may reduce the likelihood of future disappointments. 
Since the early 1990s, more Chinese state-owned firms are being listed in various stock exchanges in Mainland China, Hong Kong and in other countries such as US. As this trend continues, financing from equity markets becomes a more important source of capital for Chinese state-controlled firms. In these firms, the government holds the control rights to make decisions of appointing top management and determining important strategies/policies. However, the levels of control rights held by the government are different across these state-controlled firms. Higher control rights imply larger economic interests are vested in the firm and give the government more power to monitor the managers. It is also easier for higher control rights to draw attention from the public to the potential expropriation risk of minority shareholders by controlling shareholders (Watts, 2003; Lafond and Roychowdhury, 2008). Therefore, the statecontrolled firms with high control rights held by the government should have greater levels of conditional conservatism.

Some other important firm-level variables can also affect conditional conservatism. For example, in the last three decades, the institutional environment that affects the objectives of state-controlled firms in running their business, the role of government, the attitude toward investors, and the accounting policy, in particular conditional conservatism has changed significantly (Ezzamel et al., 2007). However, it takes time for firm culture, policies and management style to reflect the institutional environment change. Ezzamel et al. (2007) suggest that "...dominant political ideology creates a context that can discourage, but never forecloses, the scope for debate on alternative accounting practices because elements are never fully transformed into moments with fixed meanings". In the year of 1992, the Ministry of Finance issued an important document i.e. the Accounting System for Companies Experimenting with Shareholding System (Ministry of Finance, 1992). 
In general, compared to firms established before 1992, firms established after 1992 are younger and more quickly respond to changes, such as pursuit of innovation, business/industry growth and regulatory change (Jovanovic, 1982; Pakes and Ericson, 1998). Therefore, firms established before this significant change in 1992 could react to this change differently from those firms established after 1992. This could lead to differences in conditional conservatism dependent on the year of incorporation before or after 1992.

Another way of mitigating agency costs between shareholders and managers is the level of dividend payments. Dividend payments should have a substitution effect with other means of controlling agency costs (Easterbrook, 1984). Louis and Urcan (2015) investigate a sample of US firms and find that conditional accounting conservatism can be a substitute to dividend payments in reducing agency conflicts. Therefore, it is worthwhile to consider the effect of dividend payments on the association between high control rights and conditional conservatism.

The analysis is conducted on a sample of state-controlled firms listed on Hong Kong Stock Exchange (HKSE) from 1997 to 2013. The sample period starts from 1997 as only a small number of state-controlled firms were listed on HKSE before 1997 and the sample period ends in 2013 because the Shanghai-Hong Kong Stock Connect program was launched in 2014 [3]. These firms are within an equivalent institutional environment in terms of legal system, accounting standards and economy and market development, which mitigates the influences of these environmental factors on firms' accounting policy. In addition, Hong Kong is in line with developed countries in terms of law, regulation and free market development. Data on who ultimately controls the firms is manually collected and a firm is categorized as state-controlled if 
the state holds the highest ultimate control rights (the state is the ultimate controlling shareholder).

This paper applies the timeliness to news model (Basu, 1997) and there are four main results. Firstly, state-controlled firms with high leverage exhibit weak or no conditional conservatism, which is consistent with Chen et al., (2010). Secondly, for the first time to our knowledge, this study finds that the extent of conditional conservatism in state-controlled firms increases when the leverage ratio decreases from high to low and to zero levels. This suggests there may be other sources of demand for conditional conservatism in state-controlled firms when the debt demand for conservatism decreases. Thirdly, the result shows that the high control rights held by controlling shareholders in state-controlled firms are positively associated with conditional conservatism. This suggests that the equity demand for conservatism from controlling shareholders is important in driving conditional conservatism in state-controlled firms. Fourthly, further analyses document an offsetting effect between high control rights and firm leverage; a reinforcing effect between high control rights and year of incorporation after 1992; and a substituting effect between high control rights and dividend payments.

This study makes several contributions to the literature. Complementing the literature on the debt demand for conditional conservatism, this study shows a demand for conditional conservatism from equity investors. In state-controlled firms with high leverage where debt demand dominates, there is little or no conditional conservatism; and in state-controlled firms with low or zero leverage there is evidence of conditional conservatism. In addition, the effect of high control rights held by controlling shareholders has a positive influence on conditional conservatism and becomes more significant after controlling for other variables. This suggests 
controlling shareholders with high control rights demand conditional conservatism in statecontrolled firms. This study explores the demand for conditional conservatism from equity shareholders and identifies some important firm level variables that have not been considered in previous studies. Therefore a multi-factor approach helps develop a better understanding of accounting conservatism in state-controlled firms. The extent of conditional accounting conservatism can vary and depend on factors such as the firm's ownership and capital structure, as well as year of incorporation before or after 1992 and dividend payments.

This study suggests several implications to researchers, investors and regulators on statecontrolled firms and capital markets. The findings add to the literature on agency conflicts in firms with concentrated ownership (Claessens et al., 2000). The conservatism demanded from equity investors can serve as a means to contain management's opportunistic behavior in statecontrolled firms. In the evaluation of state-controlled firms, especially those with low or zero levels of debt, attention should be paid to how timely accounting income responds to bad news. Institutional reforms in the capital markets should encourage the active participation of investors, the demand for conditional conservatism from equity investors and the protection of the interest of minority shareholders. Also as agency cost control mechanisms are costly (Easterbrook 1984), the corporate governance mechanism at the firm level can be designed to take into account the possible substituting effects between agency control mechanisms. For example, recently the Chinese equity market regulator encouraged listed firms to pay "reasonable" levels of dividends and stated that they would take tough measures against firms that do not pay cash dividends in 
spite of being able to do so. For some firms, such as those in the beginning or growth stage of their life cycle where reinvestment is important, the cost of dividend payments can be prohibitive. Therefore as an alternative agency control mechanism conditional accounting conservatism could serve as an effective alternative to dividend payments.

The paper proceeds as follows. Section 2 briefly reviews the literature on debt demand and equity demand for conditional conservatism, corporate governance in state-controlled firms and develops testable hypotheses. Section 3 describes the research design and sample. Section 4 presents the results and Section 5 concludes the paper.

\section{Literature Review and Hypotheses Development}

\subsection{The debt demand and equity demand for conditional conservatism}

In the literature on the contracting determinants of conditional conservatism, there are at least two sources driving the demand - the debt market demand and the equity market demand perspectives (Watts, 2003). The value of debt is more asymmetrically sensitive to decreases rather than increases in firm value (downside risk). Many contractual rights/covenants of debt holders are expressed in terms of financial statement variables. Conditional conservatism can help debt holders to discover early any violation of the terms in contracts and therefore have the opportunity to take protective actions (Ball et al., 2008; Nikolaev, 2010).

The traditional agency view argues that managers tend to report too aggressively either because they are over optimistic or for strategic reasons. Conditional accounting conservatism provides a mechanism to mitigate the opportunistic tendencies of managers' and therefore is valued by shareholders (Watts, 2003). Some studies support this perspective, for example, it has 
been found that conditional conservatism benefits equity investors and corporate governance is positively associated with conditional conservatism (Garcia Lara et al., 2009; Louis and Urcan, 2015).

Prior research also suggests an investor attraction perspective on the equity demand for conditional conservatism. Based on evidence from other disciplines, Hirshleifer and Teoh (2009) suggest individuals process gains and losses differently and the aversion to being disappointed outweighs the upside of being satisfied. For investors, the recognition of profits or assets depends on a forecast of the future. Conditional conservatism, with a more timely recognition of losses than gains, makes the forecast lower and thus reduces the likelihood that the forecast will disappoint investors. Therefore, according to this perspective investors who are wary of future disappointments should demand conservative accounting policies (see Hirshleifer and Teoh, 2009 for a full discussion).

\subsection{Corporate governance in state-controlled firms}

Since the beginning of reforms, the Chinese government has been using market mechanism instead of administrative order to control and monitor the performance of state-controlled firms, and shares the risks and profits with other investors. State-controlled firms have raised substantial capital from various equity markets in the world, including Mainland China, US, Singapore and Hong Kong. In effect the government is acting as the controlling shareholder in these state-controlled firms and the government as the largest shareholder could expropriate the interest of minority shareholders because of making decisions based on political considerations (Shleifer, 1998). 
Managers in state-controlled firms could be less aligned with investors/shareholders, as they can be government officials or assigned by government officials. Managers of statecontrolled firms can often have other goals than improving shareholders' wealth (Shleifer, 1998). There are potentially significant agency conflicts between shareholders and managers in statecontrolled firms. In general, corporate governance is viewed weak in state-controlled firms and the quality of corporate governance varies across firms. According to the survey on the corporate governance standards of firms listed on HKSE conducted by the Hong Kong Institute of Directors and Hong Kong Baptist University, the level of corporate governance in state-controlled firms has improved significantly since 2009 (HKIoD, 2012).

\subsection{Hypotheses Development}

According to investor attraction perspective, shareholders should process gains and losses asymmetrically and they dislike future disappointments. Therefore shareholders can demand for conditional conservatism in state-controlled firms. According to the agency view, no matter whether firms are equity financed from the stock market or self-financed from internally generated capital [4], there is a need from shareholders for conditional conservatism in statecontrolled firms where managers have a motivation to deliberately overstate their profits in order to meet targets and receive bonuses (Liao, 1989). Therefore the use of conservative accounting policies in Chinese state-controlled firms has been encouraged in recent years (Ezzamel et al., 2007).

As the government is the controlling shareholder and a provider of security, the default probability is inherently lower in state-controlled firms rather than other organizational structures. Moreover, state-controlled banks have a political objective to financially support state-controlled firms (Chen et al., 2010), which further protects creditors from losses caused by potential default. 
Therefore, the debt demand for conditional conservatism in state-controlled firms is generally lower than other forms of firm ownership. In state-controlled firms with high leverage, the low debt demand for conditional conservatism could dominate the equity demand for conditional conservatism. Therefore, state-controlled firms with higher leverage would exhibit low conditional conservatism as a whole. In contrast, in state-controlled firms with low or zero leverage, the equity demand plays the dominant role and these firms could exhibit high conditional conservatism. In summary, the equity demand for conditional accounting conservatism is more prominent in state-controlled firms with low or zero leverage. Therefore the first hypothesis is as follows:

H1: State-controlled firms with low or zero leverage exhibit more conditional accounting conservatism.

As the controlling shareholder in state-controlled firms, the government obtains economic interests through their shareholdings. There can be agency conflicts between managers and the controlling shareholder in state-controlled firms; and these costs might be high for firms with high government share-holding. Accounting conservatism has been encouraged by regulators (Ezzamel et al., 2007), because it is an effective tool to protect long-term interests of shareholders, the controlling shareholder in particular, and to help address market uncertainty and improve the reliability of accounting information, and benefits controlling shareholder/government (Li, 2001).

In addition, in firms with controlling shareholders, the risk of expropriation of minority shareholders could discourage the participation of small investors. For state-controlled firms, large profits could easily draw the attention from the public and may undergo political scrutiny. 
Therefore, in order to protect the interests of minority shareholders and avoid the potential political costs, the demand for conditional conservatism is higher in state-controlled firms with a higher government controlling stake. Therefore, the second hypothesis is as follows:

H2: State-controlled firms with high government control stake exhibit more conditional accounting conservatism.

\section{Research Design}

\subsection{Measure of accounting conservatism}

The timeliness of earnings to news (Basu, 1997) is used as the measure of conditional accounting conservatism. This examines the extent of timeliness to which accounting income responds to good news (proxied by positive stock returns) versus bad news (proxied by negative stock returns). The piecewise linear regression is specified in Equation (1). The asymmetric recognition of bad news relative to good news is captured by a positive $\beta_{3}$, the coefficient on $D R_{i t} * R_{i t}$

$$
N I_{i t}=\beta_{0}+\beta_{1} D R_{i t}+\beta_{2} R_{i t}+\beta_{3} D R_{i t} * R_{i t}+\varepsilon
$$

where subscripts $i$ and $t$ stand for firm and year respectively. $N I_{i t}$ is the net income before extraordinary items for firm $i$ and year $t$ deflated by the beginning-of-year market value, $R_{i t}$ is the stock return for firm $i$ over the fiscal year $t$, and $D R_{i t}$ is a dummy variable that equals 1 if $R_{i t}$ is less than zero, and 0 otherwise.

\subsection{Sample and data}


The sample in this study selects state-controlled firms listed in HKSE instead of firms listed in Mainland China out of the following consideration/motivation. This study attempts to explore the equity demand for conditional conservatism in state-controlled firms. The relatively underdeveloped stock market in Mainland China could blur the relationship between equity demand and conservatism in state-controlled firms. In addition, Hong Kong is in line with developed countries in terms of legal system, accounting standards and economy and market development. This is important because the return-based timely loss recognition measures assume market efficiency (Dechow et al., 2010). According to the criteria proposed by La Porta et al. (1998), Hong Kong law is in the common law family and Hong Kong scores five out of six in the shareholder rights measures; the financial market, the corporate governance practice and accounting standards in Hong Kong are at a development level comparable to developed economies (Cheung et al., 2007).

The initial sample starts with the firms listed on the Main Board of Hong Kong Stock Exchange (HKSE). These firms are ranked from high to low according to the market capitalization and the ultimate control data is hand collected for 312 industrial firms excluding financial and utility firms. The firm's ultimate controlling shareholder (controlling shareholder hereafter) is defined as the largest shareholder in the control chain with the absolute majority of voting rights and at least five percent of the ultimate control rights (La Porta et al., 1999). A firm is defined as state-controlled if the ultimate controlling shareholder is the government. Finally, 87 out of 312 firms are identified as state-controlled firms. 
The sample period is from 1997 to 2013 . Before 1997, not many state-controlled firms were listed in Hong Kong. Claessens et al. (2000) find only 3\% of firms are state-controlled in their sample of 330 firms listed in HKSE as of the end of 1996 or the closest date. However after this date with further opening up of China regulations and deepening reforms, more and more state-controlled firms from Mainland China get listed in HKSE. In 2014, the Chinese government launched the Shanghai-Hong Kong Stock Connect program. This program for the first time allows the Mainland China investors (Hong Kong investors) to directly trade shares listed on HKSE (Shanghai Stock Exchange) and dramatically changed the stock return pattern in both markets. Hence the sample period ends in 2013 to avoid the effect of this program on the return-based conditional conservatism measure.

Firm-year observations with missing data are deleted. To eliminate the effect of outliers, the independent, dependent and control variables are winsorized at the $1 \%$ level. This leaves 849 firm-year observations for state-controlled firms. In some of the tests, the numbers of observations are reduced due to different data requirements.

\section{Data Analysis}

\subsection{Preliminary result}

To test Hypothesis 1, leverage is used to measure the level of debt and is defined as debt divided by total assets at the end of the year $t-1$. Following the methodology in Louis and Urcan (2015), firms are split into a high leverage group where the leverage is higher than $15.8 \%$ (median of all firms in our sample), a low leverage group where the leverage of firms is below $15.8 \%$, a very 
low leverage group where the leverage of firms is below $3 \%$ (the $5^{\text {th }}$ percentile of all firms in our sample), and a zero leverage group where the leverage of firms is zero.

Table 1 presents the regression results for high leverage, low leverage, very low leverage and zero leverage firms in Panel A, Panel B, Panel C and Panel D respectively. The coefficient on $D R * R$ in state-controlled firms is insignificantly positive $(0.038)$ for high leverage firms, insignificantly positive $(0.060)$ for low leverage firms, but is significantly positive $(0.136)$ at the $10 \%$ level for very low leverage firms, and is significantly positive $(0.312)$ at the $5 \%$ level for zero leverage firms. Lower conditional conservatism in high leverage firms indicates the dominant role of the debt demand for conditional conservatism, but the higher conditional conservatism in very low and zero leverage firms are mainly attributable to other factors such as equity demand because debt demand is low or zero. These results showing a difference in the level of conditional conservatism based on the leverage levels provides support for the first hypothesis $(\mathrm{H} 1)$.

$<$ Insert Table 1 here $>$

To test Hypothesis 2, the sample of state-controlled firms is split based on their control rights. High control firms refer to the firms that have control rights greater than $62 \%$ (the top quartile) and low control firms refer to the firms that have control rights lower than $41 \%$ (the bottom quartile). Panel A of Table 2 compares the descriptive statistics of high control firms versus low control firms. High control firms are more negatively skewed in earnings, lower in 
leverage, younger in establishment date and tend to pay higher dividends. Panel B of Table 2 presents Pearson correlation coefficients of main variables. Some of the correlations are above 0.2. This suggests possible interaction effect and justifies the multi-variant analysis below.

$<$ Insert Table 2 here $>$

Table 3 Panel A presents the regression results from the following model [5].

$$
\begin{aligned}
N I_{i t} & =\beta_{0}+\beta_{1} D R_{i t}+\beta_{2} R_{i t}+\beta_{3} D R_{i t} * R_{i t}+\beta_{4} \operatorname{HighCon}_{i t}+\beta_{5} \operatorname{HighCon}_{i t} * D R_{i t} \\
& +\beta_{6} \operatorname{HighCon}_{i t} * R_{i t}+\beta_{7} \operatorname{HighCon}_{i t} * D R_{i t} * R_{i t}+\varepsilon
\end{aligned}
$$

where $\mathrm{HighCon}_{i t}$ is a dummy variable that equals 1 if firm $i$ that has control rights greater than $62 \%$, and 0 if firm $i$ have control rights lower than $41 \%$. The coefficient on $H i g h \operatorname{Con}_{i t} * D R_{i t} * R_{\text {it }}$ in Table 3 is positive $(0.175)$ and significant at the $10 \%$ level, providing some weak evidence that state-controlled firms with high control rights are more conservative than firms with low control rights. This provides some support for Hypothesis 2.

$<$ Insert Table 3 here $>$

\subsection{Multi-variable analysis}

Firstly, as elaborated above, the declining debt demand for conditional conservatism in firms with decreasing level of leverage is shown in Table 1. If high control stake implies high equity demand for conditional conservatism, it is interesting to see how control stake and leverage jointly affect the conditional conservatism in state-controlled firms. 
Secondly, in the reform process of state-controlled firms, radical changes have occurred in terms of the role and functions of government and accounting conservatism. The role of government in these firms changes from economy planner, capital provider, and profit distributor to a controlling shareholder. Along with the role of government changes, accounting conservatism, originally viewed as a means of deliberately understating profits (Xin and Huang, 1951) and later allowed in Chinese-foreign joint-ventures for harmonizing international accounting practice (Ge et al., 1988), was encouraged in these firms (Ezzamel et al., 2007).

However, the historical environment can have an impact on firm behavior. For example, CEOs who grew up during the Great Depression are averse to debt and prefer to use internal finance and CEOs with military experience pursue more aggressive policies, including higher leverage (Malmendier et al., 2011). Also Ezzamel et al. (2007) suggest that “...dominant political ideology creates a context that can discourage, but never forecloses, the scope for debate on alternative accounting practices because elements are never fully transformed into moments with fixed meanings". Therefore, the different speed at which firms react to these changes could induce different conditional conservatism in state-controlled firms. For example, the year of 1992 is a critical time point in the transformation of institutional environment facing statecontrolled firms, as in that year an important political and legal document, the Accounting System for Companies Experimenting with Shareholding System, was issued (Ministry of Finance, 1992). From this time on, the government became the major shareholder of statecontrolled firms and minority shareholders were legally treated as a contributor of finance to a firm and had legal rights to share in the profit of the firm. 
In addition, firms incorporated before 1992 are older than firms incorporated after 1992. Facing changes such as pursuit of innovation, business/industry growth and regulatory change, old firms usually tend to be slower in response, take longer transition period and incur higher cost (Jovanovic, 1982; Pakes and Ericson, 1998). Therefore the firm objectives, culture and style of management of state-controlled firms established before 1992 would be different from those firms established after 1992. This could lead to differences in conditional conservatism.

Thirdly, various corporate governance tools can substitute for each other. Although high control rights held by controlling shareholders can be effective in aligning the interests between managers and shareholders, dividend payments can also serve as an important tool in disciplining management and controlling agency costs (Easterbrook, 1984). Louis and Urcan (2015) find a negative relation between dividend payments and accounting conservatism.

To examine the joint effects of leverage, establishment date and dividends with control rights, the following model (3) is estimated:

$$
\begin{aligned}
N I_{i t}= & \beta_{0}+\beta_{1} D_{i t}+\beta_{2} R_{i t}+\beta_{3} D R_{i t} * R_{i t}+\beta_{4} \text { HighCon }_{i t}+\beta_{5} \text { HighCon }_{i t} * D R_{i t} \\
& +\beta_{6} \text { HighCon }_{i t} * R_{i t}+\beta_{7} \text { HighCon }_{i t} * D R_{i t} * R_{i t}+\beta_{8} X_{i t}+\beta_{9} X_{i t} * D R_{i t} \\
& +\beta_{10} X_{i t} * R_{i t}+\beta_{11} X_{i t} * D R_{i t} * R_{i t}+\varepsilon
\end{aligned}
$$

where $X_{i t}$ is alternatively each of the three variables Lev $_{i t}$, Young $_{i t}$ and Div $v_{i t}$ Div $v_{i t}$ is debt divided by total assets at the end of the year $t-1$. Young $_{i t}$ is a dummy variable that is 1 if a firm is incorporated after 1992 and 0 otherwise; Div $i t$ is a proxy for dividends payment measured as total dividends divided by total assets; and all other variables are defined as before. A positive $\beta_{7}$, the coefficient on $\operatorname{HighCon}_{i t} * D R_{i t} * R_{i t}$, would indicate higher conditional conservatism in statecontrolled firms with high control rights than in firms with low control rights. A positive $\beta_{11}$, the 
coefficient on $X_{i t}{ }^{*} D R_{i t} * R_{i t}$, would indicate that the factor measured by $X_{i t}$ is positively associated with conditional conservatism.

Table 3 Panel B shows the joint effect of control rights and leverage. The coefficient on $\operatorname{HighCon}_{i t} * D R_{i t} * R_{i t}$, remains positive (0.180) and the significance increases to $5 \%$ level; and the coefficient on $\operatorname{Lev}_{i t} * D R_{i t} * R_{i t}$, is negative (-0.451) and significant at the $10 \%$ level. This suggests the offsetting effect of control right and leverage on conditional conservatism. Even though the debt demand for conditional conservatism is low, the demand from the high control stakeholders (government) induces conditional conservatism in state-controlled firms.

Table 3 Panel $\mathrm{C}$ shows the joint effect of control rights and the year the firm was incorporated. The coefficient on $\operatorname{HighCon}_{i t}{ }^{*} D R_{i t} * R_{i t}$, remains positive (0.138) and the significance increases to $5 \%$ level; and the coefficient on $\operatorname{Young}_{i t} * D R_{i t} * R_{i t}$, is also positive (0.218) and significant at the $10 \%$ level. This suggests a reinforcing effect of control right and year of incorporation after 1992 on conditional conservatism as the demand for conditional conservatism is even higher in state-controlled firms incorporated after 1992.

Table 3 Panel D shows the joint effect of control rights and dividends payment. The coefficient on $\operatorname{HighCon}_{i t} * D R_{i t} * R_{i t}$, remains positive (0.204) and the significance increases to $5 \%$ level; and the coefficient on $D i v_{i t} * D R_{i t} * R_{i t}$, is negative (-2.781) and significant at the $10 \%$ level. This suggests a substituting effect of control right and dividends on conditional conservatism. High dividend payment serves as a corporate governance tool and reduces the demand for conditional conservatism and the demand for conditional conservatism from high control remains high. 


\subsection{Additional analysis}

The analysis below incorporates all variables into one model and the specification of the model (4) is as follows:

$$
\begin{aligned}
N I_{i t}= & \beta_{0}+\beta_{1} D_{i t}+\beta_{2} R_{i t}+\beta_{3} D_{i t} * R_{i t}+\beta_{4} \text { HighCon }_{i t}+\beta_{5} \text { HighCon }_{i t} * D R_{i t} \\
& +\beta_{6} \text { HighCon }_{i t} * R_{i t}+\beta_{7} \text { HighCon }_{i t} * D R_{i t} * R_{i t}+\beta_{9} \text { Lev }_{i t}+\beta_{10} \text { Lev }_{i t} * D R_{i t} \\
& +\beta_{11} \text { Lev }_{i t} * R_{i t}+\beta_{12} \text { Lev }_{i t} * D R_{i t} * R_{i t}+\beta_{13} \text { Young }_{i t}+\beta_{14} \text { Young }_{i t} * D R_{i t} \\
& +\beta_{15} \text { Young }_{i t} * R_{i t}+\beta_{16} \text { Young }_{i t} * D R_{i t} * R_{i t}+\beta_{17} \text { Div }_{i t}+\beta_{18} \text { Div }_{i t} * D R_{i t} \\
& +\beta_{19} \text { Div }_{i t} * R_{i t}+\beta_{20} \text { Div }_{i t} * D R_{i t} * R_{i t}+\beta_{21} \text { Size }_{i t}+\beta_{22} \text { Size }_{i t} * D R_{i t} \\
& +\beta_{23} \text { Size }_{i t} * R_{i t}+\beta_{24} \text { Size }_{i t} * D R_{i t} * R_{i t}+\beta_{25} M B_{i t}+\beta_{26} M B_{i t} * D R_{i t} \\
& +\beta_{27} \text { MB }_{i t} * R_{i t}+\beta_{28} M B_{i t} * D R_{i t} * R_{i t} \varepsilon
\end{aligned}
$$

where $S I Z E_{i t}$ is the natural $\log$ of total assets at the end of year $t-1 ; M B_{i t}$ is calculated as the market value of equity divided by the book value of equity at the end of year $t-1$; and all other variables are defined as before.

Table 4 reports the estimates from equation (4). Model 1 examines the joint effect of the variables of HighCon $i t$, Lev $_{i t}$, Young $i t$ and Divit; and Model 2 the joint effect of all the variables including $S_{i z} e_{i t}$ and $M B_{i t}$ ratio. In both models, the coefficient on $\operatorname{HighCon}_{i t}{ }^{*} D R_{i t} * R_{i t}$, remains positive and the significance increases to $1 \%$ level; and the coefficient on other variables become less significant. This indicates the demand for conditional conservatism from high control rights is dominant and the effect of other variables is reduced.

$<$ Insert Table 4 here $>$ 


\section{Conclusions}

This study explores the demand for conditional accounting conservatism from equity investors in state-controlled firms. If leverage proxies for debt pressure for conditional conservatism, then low or zero leverage indicates low or no debt demand for conditional conservatism. Following the methodology in the study by Louis and Urcan (2015), state-controlled firms are divided into subgroups according to different leverage levels. State-controlled firms with high leverage exhibits no conditional conservatism but firms with low and zero leverage exhibits higher levels of conditional conservatism [6].

Further analysis explores possible factors that induce conditional conservatism in statecontrolled firms. The controlling shareholders with high control rights are considered as an important source of equity demand for conditional conservatism in low and zero leverage firms. This hypothesis is supported by the positive association between high control rights and conditional conservatism in the timeliness of earnings to news model.

To examine whether important firm level variables in addition to control rights are associated with incrementally significant effects on conditional conservatism, separate analyses are conducted on the joint effect of high control rights, leverage, year of incorporation before or after 1992 and dividend payments on conditional conservatism. The results show an offsetting effect between high control and leverage, a reinforcing effect between high control and year of incorporation after 1992, and a substituting effect between high control rights and dividend payments. In all results, including incorporating all variables into one model, high control rights 
remain significantly positive. This is consistent with the hypothesis suggesting the demand from equity shareholders with high control can be an important source inducing conditional conservatism in state-controlled firms.

Finally, this study notes some limitations. This study is exploratory in nature and is not intended to establish causality between variables. The timeliness of earnings to news model (Basu, 1997) is used as a measure of conditional conservatism because this measure is relevant to the purpose of this study or the equity demand for conservatism, but it has well-documented limitations (Khan and Watts, 2009; Ball et al., 2013). Although this study discusses the effect of some important firm level variables on conditional conservatism, there are certainly other omitted variables including for example, CG-scores. All of these concerns deserve further research. 


\section{References}

Ball, R., Kothari, S. P., Nikolaev, V. (2013) "Econometrics of the Basu asymmetric timeliness coefficient and accounting conservatism." Journal of Accounting Research $51,1071-1097$.

Ball, R., Robin, A., Sadka, G. (2008). "Is financial reporting shaped by equity markets or by debt markets? An international study of timeliness and conservatism". Review of Accounting Studies 13, 168-205.

Basu, S. (1997). "The conservatism principle and the asymmetric timeliness of earnings". Journal of Accounting and Economics 24, 3-37.

Chen, H., Chen, J. Z., Lobo, G. J., Wang, Y. (2010). “Association between borrower and lender state ownership and accounting conservatism”. Journal of Accounting Research 48, 973-1014.

Cheung, Y. L., Connelly, J. T., Limpaphayom, P., Zhou, L. (2007). "Do investors really value corporate governance? Evidence from the Hong Kong market”. Journal of International Financial Management and Accounting 18, 86-121.

Claessens, S., Djankov, S., Lang, L. H. P. (2000). “The separation of ownership and control in East Asian corporations". Journal of Financial Economics 58, 81-112.

Dechow, P., Ge, W., Schrand, C. (2010). "Understanding earnings quality: A review of the proxies, their determinants and their consequences". Journal of Accounting and Economics 50, 344-401. 
Dickhaut, J., Basu, S., McCabe, K., Waymire, G. (2010). "Neuroaccounting: Consilience between the biologically evolved brain and culturally evolved accounting principles". Accounting Horizons 24, 221-255.

Easterbrook, F. (1984). "Two agency-cost explanations of dividends". American Economic Review 74, 650-659.

Ezzamel, M., Xiao, J. Z., Pan, A. (2007). "Political ideology and accounting regulation in China”. Accounting, Organizations and Society 32, 669-700.

Garcia Lara, J., Garcia Osma, B., Penalva, F. (2009). “The economic determinants of conditional conservatism". Journal of Business Finance and Accounting 36, 336-372.

Ge, J. S., Lin, Z. J., Wei, M. H. (1988). "Application of conservatism to the accounting system for firms using foreign investment”. Accounting Research 5, 19-22. Hirshleifer, D., Teoh, S. H. (2009). "The psychological attraction approach to accounting and disclosure policy". Contemporary Accounting Research 26, 1067 1190.

Hong Kong Institute of Directors (“HKIoD”) (2012). "Survey finds significant improvement in corporate governance among Hong Kong-listed companies". http://www.hkiod.com

Jovanovic, B. (1982), "Selection and the evolution of industry", Econometrica 50, 649-670.

Khan, M., Watts, R. (2009). "Estimation and empirical properties of a firm-year measure of accounting conservatism." Journal of Accounting and Economics 48, $132-$ 150. 
Lafond, R., Roychowdhury, S. (2008). "Managerial ownership and accounting conservatism”. Journal of Accounting Research 46, 101-135.

La Porta, R., Lopez-de-Silanes, F., Shleifer, A., Vishny, R. W. (1998). "Law and finance". Journal of Political Economy 106, 1113-1155.

La Porta, R., Lopez-de-Silanes, F., Shleifer, A. (1999). “Corporate ownership around the world". Journal of Finance 44, 471-517.

Li, Y. (2001). A major measure for developing an accounting system suitable for China - The issue of the Enterprise Accounting System. China Finance and Economics Newspaper. <http://www.e521.com/cksj/yjyw/0036.htm>.

Liao, C. J. (1989). "Personal views on the application of conservatism". Yunnan Accounting 5, 26-28.

Louis, H., Sun, A., Urcan, O. (2012). "Value of cash holdings and accounting conservatism”. Cotemporary Accounting Research 29, 1249-1271.

Louis, H., Urcan, O. (2015). "Agency conflicts, dividend payout, and the direct benefits of conservative financial reporting to equity holders". Contemporary Accounting Research 32, 455-484.

Malmendier, U., Tate, G., Yan, J. (2011). “Overconfidence and early-life experiences: The effect of managerial traits on corporate financial policies". Journal of Finance 66, $1687-1733$.

Ministry of Finance (1992). Accounting system for experimental shareholding enterprises. Beijing, China: The Ministry of Finance. 
Nikolaev, V. (2010). "Debt covenants and accounting conservatism.” Journal of Accounting Research 48, 51-89.

Pakes, A. and R. Ericson (1998), "Empirical Implications of Alternative Models of Firm Dynamics", Journal of Economic Theory 79, 1-45.

Petersen, M. A. (2009). "Estimating standard errors in finance panel data sets: Comparing approaches”. Review of Financial Studies 22, 435-480.

Shleifer, A. (1998). "State versus private ownership". Journal of Economic Perspectives 12, 133-150.

Xin, Z., Huang, S. (1951). "How to construct new China's theoretical accounting basis". New Accounting 1, 12-16.

Watts, R. (2003). “Conservatism in accounting, Part I: Explanations and implications”. Accounting Horizons 17, 207-221. 
Notes:

[1] Basu (1997) defines conditional conservatism as a "higher degree of verification to recognize good news as gains than to recognize bad news as losses."

[2] Watts (2003) suggests that “conservatism benefits users of the firm's accounting reports. One explanation is that conservatism arises because it is part of the efficient technology employed in the organization of the firm and its contracts with various parties. Under this contracting explanation, conservative accounting is a means of addressing moral hazard caused by parties to the firm having asymmetric information, asymmetric payoffs, limited horizons, and limited liability. For example, conservatism can contain management's opportunistic behavior in reporting accounting measures used in a contract".

[3] The Shanghai-Hong Kong Stock Connect program has been expected to narrow the price differences for shares of Chinese companies listed in the Shanghai Stock Exchange (A shares) and in the Hong Kong Stock Exchange (H shares). The price differences between the $\mathrm{A}$ and $\mathrm{H}$ shares narrowed significantly over the third quarter of 2014 (BIS Quarterly Review, December 2014). http://www.bis.org/publ/qtrpdf/r_qt1412u.htm).

[4] Self-financing could lead to less efficient use of internal capital and increase the agency conflicts between manager and shareholders. Louis et al. (2012) find accounting conservatism can mitigate the value destruction associated with cash holdings.

[5] In the estimation of equation 2 and equation 3, the cluster-robust error estimation controls both time fixed effect and firm fixed effect (Petersen, 2009).

[6] For comparison, the same analysis is also conducted on a sample of familycontrolled firms listed in HKSE (see Table A in Appendix). There is no substantial difference in the conditional conservatism between groups with different leverage levels. Or in contrary to the findings on state-controlled firms, the variation in conditional conservatism in different leverage groups is not found in familycontrolled firms. 
Table 1: Regression analysis for state-controlled firms with different leverage levels

\begin{tabular}{|c|c|c|}
\hline Panel A: (firms with leverage above median $15.8 \%$ ) & \multicolumn{2}{|c|}{ Dependent Variable: NI } \\
\hline Independent Variable & Coefficient & $\mathrm{t}$-value \\
\hline INTERCEPT & $0.064 * *$ & 2.39 \\
\hline$D R$ & -0.037 & -1.59 \\
\hline$R$ & 0.034 & 1.21 \\
\hline$D R * R$ & 0.038 & 0.52 \\
\hline Adj. $R^{2}(\%)$ & 6.4 & \\
\hline Obs. & 484 & \\
\hline Panel B: (firms with leverage below median15.8\%) & \multicolumn{2}{|c|}{ Dependent Variable: NI } \\
\hline Independent Variable & Coefficient & t-value \\
\hline INTERCEPT & $0.078 * * *$ & 6.75 \\
\hline$D R$ & -0.004 & -0.24 \\
\hline$R$ & $0.033^{* *}$ & 2.18 \\
\hline$D R * R$ & 0.060 & 1.55 \\
\hline Adj. $R^{2}(\%)$ & 9.8 & \\
\hline Obs. & 365 & \\
\hline Panel C: (firms with leverage below 3\%) & \multicolumn{2}{|c|}{ Dependent Variable: NI } \\
\hline Independent Variable & Coefficient & t-value \\
\hline INTERCEPT & $0.080 * * *$ & 5.51 \\
\hline$D R$ & 0.016 & 0.67 \\
\hline$R$ & 0.005 & 0.23 \\
\hline$D R * R$ & $0.136^{*}$ & 2.00 \\
\hline Adj. $R^{2}(\%)$ & 7.1 & \\
\hline Obs. & 123 & \\
\hline Panel D: (firms with zero leverage) & \multicolumn{2}{|c|}{ Dependent Variable: NI } \\
\hline Independent Variable & Coefficient & t-value \\
\hline INTERCEPT & $0.075 * * *$ & 4.21 \\
\hline$D R$ & 0.038 & 1.17 \\
\hline$R$ & -0.059 & -1.30 \\
\hline$D R * R$ & $0.312^{* *}$ & 2.55 \\
\hline Adj. $R^{2}(\%)$ & 24.3 & \\
\hline Obs. & 53 & \\
\hline
\end{tabular}

Table 1 presents estimates of conditional accounting conservatism in state-controlled firms with different leverage levels using the following regression model:

$N I_{i t}=\beta_{0}+\beta_{1} D R_{i t}+\beta_{2} R_{i t}+\beta_{3} D R_{i t} * R_{i t}+\varepsilon$

$N I_{i t}$ is the net income before extraordinary items for firm $i$ and year $t$ deflated by market value in year $t-1 . R_{i t}$ is the stock return for firm $i$ in year $t . D R_{i t}$ is a dummy variable that equals 1 if $R_{i t}$ is less than zero, and 0 otherwise. The sample period is from 1997 to 2013. The t-statistics are based on cluster-robust standard errors controlling for year fixed effect and firm fixed effect. ***, ** and * indicate significance at the $1 \%, 5 \%$ and $10 \%$ levels respectively. 
Table 2: Descriptive statistics (high control vs. low control firms)

\begin{tabular}{|c|c|c|c|c|c|c|c|c|c|}
\hline \multicolumn{2}{|l|}{ Panel A: } & \multicolumn{2}{|c|}{ High Control } & \multicolumn{6}{|c|}{ Low Control } \\
\hline variable & Obs. & Mean & $\begin{array}{l}\text { Std. } \\
\text { Dev }\end{array}$ & Median & Obs. & Mean & $\begin{array}{l}\text { Std. } \\
\text { Dev }\end{array}$ & Median & $\begin{array}{l}\text { t-test } \\
\text { p-value }\end{array}$ \\
\hline Control & 191 & 0.707 & 0.064 & 0.699 & 184 & 0.313 & 0.091 & 0.338 & $<.0001$ \\
\hline$N I$ & 191 & 0.087 & 0.099 & 0.088 & 184 & 0.066 & 0.119 & 0.060 & 0.07 \\
\hline$R$ & 191 & 0.265 & 0.588 & 0.115 & 184 & 0.256 & 0.777 & 0.076 & 0.90 \\
\hline LEV & 191 & 0.174 & 0.116 & 0.159 & 184 & 0.209 & 0.149 & 0.202 & 0.01 \\
\hline Young & 191 & 0.921 & 0.270 & 1.000 & 184 & 0.690 & 0.464 & 1.000 & $<0.0001$ \\
\hline$D I V$ & 164 & 0.023 & 0.021 & 0.017 & 149 & 0.015 & 0.020 & 0.008 & 0.0005 \\
\hline SIZE & 191 & 23.979 & 1.847 & 23.814 & 184 & 22.818 & 1.450 & 22.741 & $<0.0001$ \\
\hline$M B$ & 191 & 1.903 & 1.570 & 1.588 & 184 & 2.302 & 2.195 & 1.500 & 0.04 \\
\hline \multicolumn{10}{|c|}{ Panel B: Correlation } \\
\hline & Control & $N I$ & $R$ & $L E V$ & Young & $D I V$ & SIZE & $M B$ & \\
\hline \multicolumn{10}{|l|}{ Control } \\
\hline$N I$ & $0.10^{*}$ & & & & & & & & \\
\hline$R$ & 0.02 & $0.35^{* * *}$ & & & & & & & \\
\hline$L E V$ & -0.06 & $-0.11 * *$ & 0.03 & & & & & & \\
\hline Young & $0.25^{* * *}$ & $0.14^{* * *}$ & -0.02 & -0.05 & & & & & \\
\hline$D I V$ & $0.15^{* * *}$ & 0.03 & -0.02 & $-0.16^{* * *}$ & $0.11 * *$ & & & & \\
\hline SIZE & $0.26^{* * *}$ & $0.14 * * *$ & -0.08 & $0.16^{* * *}$ & $0.22 *$ & $0.36^{* * *}$ & & & \\
\hline$M B$ & $-0.13 * *$ & -0.02 & -0.06 & $-0.14 * * *$ & $0.17 *$ & $0.20^{* * *}$ & $0.13 * *$ & & \\
\hline
\end{tabular}

The sample of state-controlled firms is split based on their control rights. High control firms refer to the firms that have control rights greater than $62 \%$ (the top quartile). Low control firms refer to the firms that have control rights lower than $41 \%$ (the bottom quartile). Table 2 presents the descriptive statistics of the main variables and control variables in the high control vs. low control firms. Control is ultimate control rights held by the largest shareholder or the government. Lev is debt divided by total assets at the end of the year t-1. Young is a dummy variable that is 1 if a firm is incorporated after 1992 and 0 otherwise. Div is a proxy for dividends payment measured as total dividends divided by total assets. SIZE is the natural log of total assets at the end of year $t-1$. LEV is debt divided by total assets at the end of the year $t-1 . M B$ is calculated as the market value of equity divided by the book value of equity at the end of year $t-1$. All other variables are defined as before. 
Table 3: Regression analysis in high control firms vs. low control firms

\begin{tabular}{|c|c|c|}
\hline Panel A: (high control vs. low control) & \multicolumn{2}{|c|}{ Dependent Variable: NI } \\
\hline Independent Variable & Coefficient & t-value \\
\hline INTERCEPT & $0.074 * * *$ & 4.07 \\
\hline$D R$ & -0.053 & -1.52 \\
\hline$R$ & $0.037 *$ & 1.98 \\
\hline$D R * R$ & -0.044 & -0.6 \\
\hline HighCon & 0.006 & 0.31 \\
\hline $\operatorname{HighCon} * D R$ & $0.064 *$ & 1.72 \\
\hline $\operatorname{HighCon} * R$ & 0.012 & 0.5 \\
\hline $\operatorname{HighCon} * D R * R$ & $0.175^{*}$ & 2 \\
\hline Adj. $R^{2}(\%)$ & 15.2 & \\
\hline Observations & 375 & \\
\hline
\end{tabular}

\begin{tabular}{|c|c|c|}
\hline Panel B: (control and leverage) & \multicolumn{2}{|c|}{ Dependent Variable: NI } \\
\hline Independent Variable & Coefficient & $\mathrm{t}$-value \\
\hline INTERCEPT & $0.086^{* * *}$ & 3.64 \\
\hline$D R$ & -0.005 & -0.12 \\
\hline$R$ & 0.016 & 0.67 \\
\hline$D R * R$ & 0.022 & 0.31 \\
\hline HighCon & 0.007 & 0.33 \\
\hline $\operatorname{HighCon} * D R$ & $0.064^{*}$ & 1.94 \\
\hline $\operatorname{HighCon} * R$ & 0.012 & 0.49 \\
\hline $\operatorname{HighCon} * D R * R$ & $0.180 * *$ & 2.09 \\
\hline Lev & -0.062 & -0.68 \\
\hline$L e v^{*} D R$ & -0.278 & -1.65 \\
\hline$L e v^{*} R$ & 0.101 & 1.08 \\
\hline$L e v * D R * R$ & $-0.451^{*}$ & -1.74 \\
\hline Adj. $R^{2}(\%)$ & 19.1 & \\
\hline Observations & 375 & \\
\hline Panel C: (control and establishment year) & \multicolumn{2}{|c|}{ Dependent Variable: NI } \\
\hline Independent Variable & Coefficient & t-value \\
\hline INTERCEPT & $0.064 *$ & 1.76 \\
\hline$D R$ & $-0.132 *$ & -1.93 \\
\hline$R$ & 0.021 & 0.64 \\
\hline$D R * R$ & -0.204 & -1.52 \\
\hline HighCon & 0.009 & 0.44 \\
\hline HighCon $* D R$ & 0.032 & 1.16 \\
\hline $\operatorname{HighCon} * R$ & -0.001 & -0.08 \\
\hline $\operatorname{HighCon} * D R * R$ & $0.138 * *$ & 2.51 \\
\hline Young & 0.009 & 0.24 \\
\hline Young $* D R$ & 0.117 & 1.65 \\
\hline Young $* R$ & 0.032 & 1.02 \\
\hline Young $* D R * R$ & $0.218^{*}$ & 1.75 \\
\hline Adj. $R^{2}(\%)$ & 18.2 & \\
\hline Observations & 375 & \\
\hline Panel D: (control and dividends) & \multicolumn{2}{|c|}{ Dependent Variable: NI } \\
\hline Independent Variable & Coefficient & t-value \\
\hline INTERCEPT & $0.076^{* * *}$ & 3.82 \\
\hline$D R$ & -0.067 & -1.62 \\
\hline$R$ & $0.037 *$ & 1.84 \\
\hline$D R * R$ & -0.040 & -0.49 \\
\hline HighCon & 0.008 & 0.38 \\
\hline
\end{tabular}




\begin{tabular}{|c|c|c|}
\hline $\operatorname{HighCon} * D R$ & $0.066^{*}$ & 1.91 \\
\hline $\operatorname{HighCon} * R$ & 0.012 & 0.49 \\
\hline $\operatorname{HighCon}^{*} D R * R$ & $0.204 * *$ & 2.4 \\
\hline Div & -0.064 & -0.42 \\
\hline$D i v * D R$ & 0.424 & 0.58 \\
\hline$D i v^{*} R$ & -0.038 & -0.09 \\
\hline$D i v^{*} D R^{*} R$ & $-2.781 *$ & -1.8 \\
\hline Adj. $R^{2}(\%)$ & 16.4 & \\
\hline Observations & 369 & \\
\hline
\end{tabular}

Table 3 Panel A presents estimates of accounting conservatism using the following regression model:

$$
\begin{aligned}
N I_{i t}= & \beta_{0}+\beta_{1} D R_{i t}+\beta_{2} R_{i t}+\beta_{3} D R_{i t} * R_{i t}+\beta_{4} \text { HighCon }_{i t}+\beta_{5} \text {HighCon }_{i t} * D R_{i t} \\
& +\beta_{6} \text { HighCon }_{i t} * R_{i t}+\beta_{7} \text { HighCon }_{i t} * D R_{i t} * R_{i t}+\varepsilon
\end{aligned}
$$

where $\mathrm{HighCon}_{i t}$ is a dummy variable that equals 1 if firm $i$ that has control rights greater than $62 \%$, and 0 if firm $i$ have control rights lower than $41 \%$.

Table 3 Panel B, Panel C and Panel D present estimates of accounting conservatism using the following regression model:

$$
\begin{aligned}
N I_{i t}= & \beta_{0}+\beta_{1} D R_{i t}+\beta_{2} R_{i t}+\beta_{3} D R_{i t} * R_{i t}+\beta_{4} H_{i g h C o n}+\beta_{5} H_{i t g h C o n}{ }_{i t} * D R_{i t} \\
& +\beta_{6} H_{i t h C o n} * R_{i t}+\beta_{7} H_{i t}{ }_{i t}{ }_{i t} * D R_{i t} * R_{i t}+\beta_{8} X_{i t}+\beta_{9} X_{i t} * D R_{i t} \\
& +\beta_{10} X_{i t} * R_{i t}+\beta_{11} X_{i t} * D R_{i t} * R_{i t}+\varepsilon
\end{aligned}
$$

where $X_{i t}$ is alternatively $L e v_{i t}$ in Panel B, Young it in Panel C and Div $v_{i t}$ in Panel D. All other variables are defined as before. The sample period is from 1997 to 2013 . The t-statistics are based on cluster-robust standard errors controlling for year fixed effect and firm fixed effect. ***, ** and * indicate significance at the $1 \%, 5 \%$ and $10 \%$ levels respectively. 
Table 4: Additional analysis

\begin{tabular}{|c|c|c|c|c|}
\hline \multicolumn{5}{|c|}{ Dependent Variable: NI } \\
\hline & Model 1 & & Model 2 & \\
\hline $\begin{array}{l}\text { Independent } \\
\text { Variable }\end{array}$ & $\begin{array}{c}\text { Coefficien } \\
t\end{array}$ & t-value & $\underset{t}{\text { Coefficien }}$ & t-value \\
\hline INTERCEPT & $0.077^{*}$ & 1.94 & -0.112 & -0.93 \\
\hline$D R$ & -0.091 & -1.15 & 0.010 & 0.05 \\
\hline$R$ & 0.006 & 0.25 & -0.117 & -0.77 \\
\hline$D R * R$ & -0.161 & -0.89 & 0.864 & 1.05 \\
\hline HighCon & 0.009 & 0.45 & -0.012 & -0.54 \\
\hline HighCon*DR & 0.037 & 1.26 & $0.070^{* *}$ & 2.09 \\
\hline $\operatorname{HighCon} * R$ & -0.001 & -0.04 & 0.000 & -0.02 \\
\hline HighCon $* D R * R$ & $0.160 * * *$ & 2.77 & $0.255^{* * *}$ & 2.95 \\
\hline Lev & -0.062 & -0.66 & -0.129 & -1.44 \\
\hline$L_{e v}^{*} D R$ & -0.223 & -1.25 & -0.099 & -0.49 \\
\hline$L e v^{*} R$ & 0.081 & 0.72 & 0.090 & 0.93 \\
\hline$L e v * D R * R$ & -0.282 & -1.02 & 0.080 & 0.22 \\
\hline Young & 0.010 & 0.27 & 0.012 & 0.41 \\
\hline Young $* D R$ & 0.108 & 1.61 & $0.106^{*}$ & 1.71 \\
\hline Young $* R$ & 0.028 & 0.78 & 0.025 & 0.73 \\
\hline Young $* D R * R$ & 0.238 & 1.55 & $0.259 *$ & 1.82 \\
\hline Div & -0.078 & -0.52 & -0.032 & -0.22 \\
\hline$D i v * D R$ & -0.277 & -0.65 & -0.366 & -0.83 \\
\hline$D i v * R$ & 0.020 & 0.06 & -0.457 & -1.07 \\
\hline$D i v^{*} D R * R$ & $-3.760 * * *$ & -2.78 & -1.775 & -0.86 \\
\hline SIZE & & & 0.010 & 1.61 \\
\hline$S I Z E^{*} D R$ & & & -0.008 & -0.65 \\
\hline$S I Z E^{*} R$ & & & 0.006 & 0.78 \\
\hline$S I Z E^{*} D R^{*} R$ & & & -0.054 & -1.24 \\
\hline$M B$ & & & -0.011 & -1.65 \\
\hline$M B^{*} D R$ & & & $0.018^{* *}$ & 2.45 \\
\hline$M B^{*} R$ & & & 0.000 & 0.03 \\
\hline$M B^{*} D R^{*} R$ & & & 0.016 & 0.83 \\
\hline Adj. $R^{2}$ & 22.1 & & 26.8 & \\
\hline Observations & 369 & & 369 & \\
\hline
\end{tabular}

Table 4 reports the estimates from the following model:

$$
\begin{aligned}
N I_{i t}= & \beta_{0}+\beta_{1} D_{i t}+\beta_{2} R_{i t}+\beta_{3} D_{i t} * R_{i t}+\beta_{4} \text { HighCon }_{i t}+\beta_{5} \text { HighCon }_{i t} * D R_{i t} \\
& +\beta_{6} \text { HighCon }_{i t} * R_{i t}+\beta_{7} \text { HighCon }_{i t} * \operatorname{DR}_{i t} * R_{i t}+\beta_{9} \text { Lev }_{i t}+\beta_{10} \text { Lev }_{i t} * D R_{i t} \\
& +\beta_{11} \text { Lev }_{i t} * R_{i t}+\beta_{12} \text { Lev }_{i t} * D R_{i t} * R_{i t}+\beta_{13} \text { Young }_{i t}+\beta_{14} \text { Young }_{i t} * D R_{i t} \\
& +\beta_{15} \text { Young }_{i t} * R_{i t}+\beta_{16} \text { Young }_{i t} * D R_{i t} * R_{i t}+\beta_{17} \text { Div }_{i t}+\beta_{18} \text { Div }_{i t} * D R_{i t} \\
& +\beta_{19} \text { Div }_{i t} * R_{i t}+\beta_{20} \text { Div }_{i t} * D R_{i t} * R_{i t}+\beta_{21} \text { Size }_{i t}+\beta_{22} \text { Size }_{i t} * D R_{i t} \\
& +\beta_{23} \text { Size }_{i t} * R_{i t}+\beta_{24} \text { Size }_{i t} * D R_{i t} * R_{i t}+\beta_{25} M B_{i t}+\beta_{26} M B_{i t} * D R_{i t} \\
& +\beta_{27} M B_{i t} * R_{i t}+\beta_{28} M B_{i t} * D R_{i t} * R_{i t} \varepsilon
\end{aligned}
$$

Model 1 examines the joint effect of the variables of HighCon $i t$, Lev $_{i t}$, Young $_{i t}$ and Div $_{i t}$; and Model 2 the joint effect of all the variables including $S i z e_{i t}$ and $M B_{i t}$ ratio. All variables are defined as before. The sample period is from 1997 to 2013. The t-statistics are based on clusterrobust standard errors controlling for year fixed effect and firm fixed effect. $* * *, * *$ and * indicate significance at the $1 \%, 5 \%$ and $10 \%$ levels respectively. 


\section{Appendix}

Table A: Regression analysis in family-controlled firms with different leverage levels

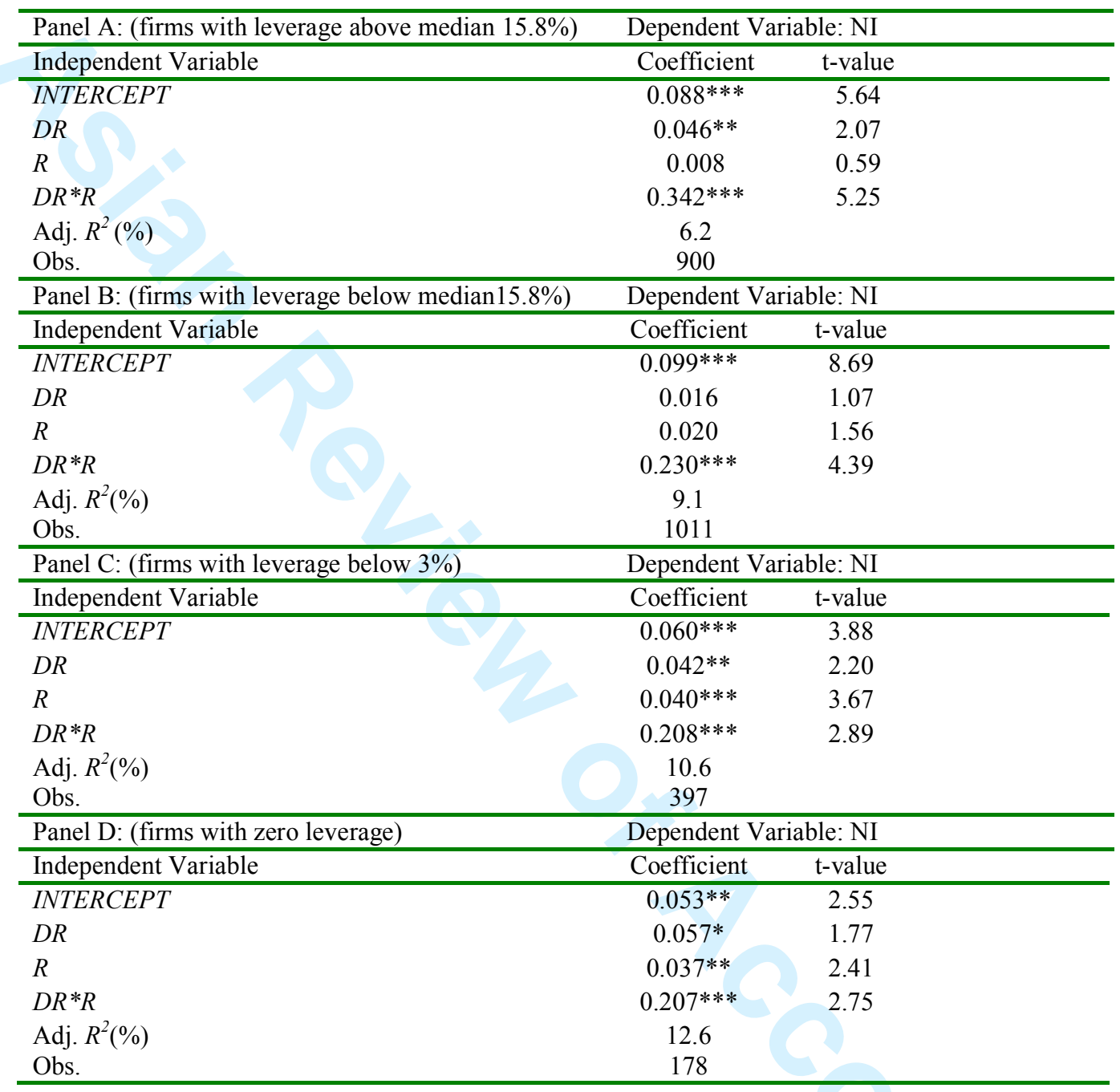

This table presents estimates of conditional accounting conservatism in family-controlled firms with different leverage levels using the following regression model:

$N I_{i t}=\beta_{0}+\beta_{1} D R_{i t}+\beta_{2} R_{i t}+\beta_{3} D R_{i t} * R_{i t}+\varepsilon$

$N I_{i t}$ is the net income before extraordinary items for firm $i$ and year $t$ deflated by market value in year $t-1 . R$ is the stock return for firm $i$ in year $t . D R_{i t}$ is a dummy variable that equals 1 if $R_{i t}$ is less than zero, and 0 otherwise. The sample period is from 1997 to 2013. The t-statistics are based on cluster-robust standard errors controlling for year fixed effect and firm fixed effect. ***, ** and * indicate significance at the $1 \%, 5 \%$ and $10 \%$ levels respectively. 


\title{
Revisiting Conditional Accounting Conservatism in State-controlled Firms
}

\begin{abstract}
This study explores the demand for conditional accounting conservatism from equity shareholders in state-controlled firms. An investigation of state-controlled firms listed on Hong Kong Stock Exchange from 1997 to 2013 shows that the extent of conditional conservatism in state-controlled firms increases when the leverage ratio decreases. It is also found that the high control rights held by the government in state-controlled firms are associated with high | conditional conservatism. In addition, further analyses document the an offsetting effect between high control rights and firm leverage; a reinforcing effect between high control rights and year of incorporation after 1992; and a substituting effect between high control rights and dividend payments. These findings suggest that the demand from equity shareholders, in addition to the debt demand, can be an important determinant of conditional conservatism and examination of these differing sources of demand can enhance the understanding on accounting conservatism in state-controlled firms.
\end{abstract}

JEL Classification: G30, G32, M41

Keywords: Conditional accounting conservatism; Equity demand; leverage; high control; Statecontrolled firms. 


\section{Introduction}

The existing literature documents that Chinese state-owned firms do not have significant levels of conditional accounting conservatism [1] (conditional conservatism hereafter) primarily due to the low demand for conservatism from the debt or bank loan market (see Chen et al., 2010). If other determinants of conditional conservatism such as litigation, regulation or tax (see Watts, 2003; Garcia Lara et al., 2009) are assumed constant, the contracting determinant encompasses more than debt contracting. Little research is conducted on the conditional conservatism in Chinese state-controlled firms with no debt. This study attempts to explore additional dimensions of contracting determinant that could induce conditional conservatism in state-controlled firms, specifically examining the equity demand for conditional conservatism [2].

Along with the debt market demand for conditional conservatism, equity investors can demand accounting conservatism because it allows shareholders to mitigate managerial motivations of opportunistic activities such as expropriation and/or poor project selection (Watts, 2003). Investigating a subsample of US firms with zero leverage, Louis and Urcan (2015) find these firms also exhibit conditional conservatism. They attribute this result to the demand for conditional conservatism from equity investors and suggest that shareholders demand accounting conservatism to mitigate agency conflicts between shareholders and managers.

The investor attraction perspective is another dimension of the equity-market demand for conditional conservatism (Hirshleifer and Teoh, 2009). This view argues that individuals process gains and losses differently (Dickhaut et al., 2010), and the relative disappointment from losses exceeds the benefits of gains. Therefore, investors would demand for conditional conservatism because conditional conservatism may reduce the likelihood of future disappointments. 
Since the early 1990s, more Chinese state-owned firms are being listed in various stock exchanges in Mainland China, Hong Kong and in other countries such as US. As this trend continues, financing from equity markets becomes a more important source of capital for Chinese state-controlled firms. In these firms, the government holds the control rights to make decisions of appointing top management and determining important strategies/policies. However, the levels of control rights held by the government are different across these state-controlled firms. Higher control rights imply larger economic interests are vested in the firm and give the government more power to monitor the managers. It is also easier for higher control rights to draw attention from the public to the potential expropriation risk of minority shareholders by controlling shareholders (Watts, 2003; Lafond and Roychowdhury, 2008). Therefore, the statecontrolled firms with high control rights held by the government should have greater levels of conditional conservatism.

Some other important firm-level variables can also affect conditional conservatism. For example, in the last three decades, the institutional environment that affects the objectives of state-controlled firms in running their business, the role of government, the attitude toward investors, and the accounting policy, in particular conditional conservatism has changed significantly (Ezzamel et al., 2007). However, it takes time for firm culture, policies and management style to reflect the institutional environment change. Ezzamel et al. (2007) suggest that "...dominant political ideology creates a context that can discourage, but never forecloses, the scope for debate on alternative accounting practices because elements are never fully transformed into moments with fixed meanings". In the year of 1992, the Ministry of Finance issued an important document i.e. the Accounting System for Companies Experimenting with Shareholding System (Ministry of Finance, 1992). 
In general, compared to firms established before 1992, firms established after 1992 are younger and more quickly respond to changes, such as pursuit of innovation, business/industry growth and regulatory change (Jovanovic, 1982; Pakes and Ericson, 1998). Therefore, firms established before this significant change in 1992 could react to this change differently from those firms established after 1992. This could lead to differences in conditional conservatism dependent on the year of incorporation before or after 1992.

Another way of mitigating agency costs between shareholders and managers is the level of dividend payments. Dividend payments should have a substitution effect with other means of controlling agency costs (Easterbrook, 1984). Louis and Urcan (2015) investigate a sample of US firms and find that conditional accounting conservatism can be a substitute to dividend payments in reducing agency conflicts. Therefore, it is worthwhile to consider the effect of dividend payments on the association between high control rights and conditional conservatism.

The analysis is conducted on a sample of state-controlled firms listed on Hong Kong Stock Exchange (HKSE) from 1997 to 2013. The sample period starts from 1997 as only a small number of state-controlled firms were listed on HKSE before 1997 and the sample period ends in 2013 because the Shanghai-Hong Kong Stock Connect program was launched in 2014 [3]. These firms are within an equivalent institutional environment in terms of legal system, accounting standards and economy and market development, which mitigates the influences of these environmental factors on firms' accounting policy. In addition, Hong Kong is in line with developed countries in terms of law, regulation and free market development. Data on who ultimately controls the firms is manually collected and a firm is categorized as state-controlled if 
the state holds the highest ultimate control rights (the state is the ultimate controlling shareholder).

This paper applies the timeliness to news model (Basu, 1997) and there are four main results. Firstly, state-controlled firms with high leverage exhibit weak or no conditional conservatism, which is consistent with Chen et al., (2010). Secondly, for the first time to our knowledge, this study finds that the extent of conditional conservatism in state-controlled firms increases when the leverage ratio decreases from high to low and to zero levels. This suggests there may be other sources of demand for conditional conservatism in state-controlled firms when the debt demand for conservatism decreases. Thirdly, the result shows that the high control rights held by controlling shareholders in state-controlled firms are positively associated with conditional conservatism. This suggests that the equity demand for conservatism from controlling shareholders is important in driving conditional conservatism in state-controlled firms. Fourthly, further analyses document-the an offsetting effect between high control rights and firm leverage; a reinforcing effect between high control rights and year of incorporation after 1992; and a substituting effect between high control rights and dividend payments.

This study makes several contributions to the literature. Complementing the literature on the debt demand for conditional conservatism, this study shows a demand for conditional conservatism from equity investors. The implication of this finding is that the demand for accounting conservatism in state-controlled firms is more complicated than previous evidence indicates. In state-controlled firms with high leverage where debt demand dominates, there is little or no conditional conservatism; and in state-controlled firms with low or zero leverage there is evidence of conditional conservatism. In addition, the effect of high control rights held by 
controlling shareholders has a positive influence on conditional conservatism and becomes more significant after controlling for other variables. This suggests controlling shareholders with high control rights demand conditional conservatism in state-controlled firms.

This study explores the demand for conditional conservatism from equity shareholders and identifies some important firm level variables that have not been considered in previous studies. Therefore a multi-factor approach helps develop a better understanding of accounting conservatism in state-controlled firms. The extent of conditional accounting conservatism can vary and depend on factors such as the firm's ownership and capital structure, as well as year of incorporation before or after 1992 and dividend payments.

This study suggests several implications to researchers, investors and regulators on statecontrolled firms and capital markets. The findings add to the literature on agency conflicts in firms with concentrated ownership (Claessens et al., 2000). The conservatism demanded from equity investors can serve as a means to contain management's opportunistic behavior in statecontrolled firms. In the evaluation of state-controlled firms, especially those with low or zero levels of debt, attention should be paid to how timely accounting income responds to bad news. Institutional reforms in the capital markets should encourage the active participation of investors, the demand for conditional conservatism from equity investors and the protection of the interest of minority shareholders. Also as agency cost control mechanisms are costly (Easterbrook 1984), the corporate governance mechanism at the firm level can be designed to take into account the possible substituting effects between agency control mechanisms. For example, recently the 
$\underline{\text { Chinese equity market regulator encouraged listed firms to pay "reasonable" levels of dividends }}$ and stated that they would take tough measures against firms that do not pay cash dividends in spite of being able to do so. For some firms, such as those in the beginning or growth stage of their life cycle where reinvestment is important, the cost of dividend payments can be prohibitive. Therefore as an alternative agency control mechanism conditional accounting conservatism $\underline{\text { could serve as an effective alternative to dividend payments. }}$

The paper proceeds as follows. Section 2 briefly reviews the literature on debt demand and equity demand for conditional conservatism, corporate governance in state-controlled firms and develops testable hypotheses. Section 3 describes the research design and sample. Section 4 presents the results and Section 5 concludes the paper.

\section{Literature Review and Hypotheses Development}

\subsection{The debt demand and equity demand for conditional conservatism}

In the literature on the contracting determinants of conditional conservatism, there are at least two sources driving the demand - the debt market demand and the equity market demand perspectives (Watts, 2003). The value of debt is more asymmetrically sensitive to decreases rather than increases in firm value (downside risk). Many contractual rights/covenants of debt holders are expressed in terms of financial statement variables. Conditional conservatism can help debt holders to discover early any violation of the terms in contracts and therefore have the opportunity to take protective actions (Ball et al., 2008; Nikolaev, 2010).

The traditional agency view argues that managers tend to report too aggressively either because they are over optimistic or for strategic reasons. Conditional accounting conservatism 
provides a mechanism to mitigate the opportunistic tendencies of managers' and therefore is valued by shareholders (Watts, 2003). Some studies support this perspective, for example, it has been found that conditional conservatism benefits equity investors and corporate governance is positively associated with conditional conservatism (Garcia Lara et al., 2009; Louis and Urcan, 2015).

Prior research also suggests an investor attraction perspective on the equity demand for conditional conservatism. Based on evidence from other disciplines, Hirshleifer and Teoh (2009) suggest individuals process gains and losses differently and the aversion to being disappointed outweighs the upside of being satisfied. For investors, the recognition of profits or assets depends on a forecast of the future. Conditional conservatism, with a more timely recognition of losses than gains, makes the forecast lower and thus reduces the likelihood that the forecast will disappoint investors. Therefore, according to this perspective investors who are wary of future disappointments should demand conservative accounting policies (see Hirshleifer and Teoh, 2009 for a full discussion).

\subsection{Corporate governance in state-controlled firms}

Since the beginning of reforms, the Chinese government has been using market mechanism instead of administrative order to control and monitor the performance of state-controlled firms, and shares the risks and profits with other investors. State-controlled firms have raised substantial capital from various equity markets in the world, including Mainland China, US, Singapore and Hong Kong. In effect the government is acting as the controlling shareholder in these state-controlled firms and the government as the largest shareholder could expropriate the 
interest of minority shareholders because of making decisions based on political considerations (Shleifer, 1998).

Managers in state-controlled firms could be less aligned with investors/shareholders, as they can be government officials or assigned by government officials. Managers of statecontrolled firms can often have other goals than improving shareholders' wealth (Shleifer, 1998). There are potentially significant agency conflicts between shareholders and managers in statecontrolled firms. In general, corporate governance is viewed weak in state-controlled firms and the quality of corporate governance varies across firms. According to the survey on the corporate governance standards of firms listed on HKSE conducted by the Hong Kong Institute of Directors and Hong Kong Baptist University, the level of corporate governance in state-controlled firms has improved significantly since 2009 (HKIoD, 2012).

\subsection{Hypotheses Development}

The most important concern for debt investors is the potential losses from default. Hence, the debt demand for accounting conservatism will be higher for firms with higher default probability. In state-controlled firms, the government is the controlling shareholder and a provider of insurance in essential and hence, the default probability is inherently lower than other organizational structures. Moreover, stateontrolled banks have a political objective to financially support state-controlled firms (Chen et al, 2010), which further protects ereditors Therefore there is more security for creditors in statecontrolled firms and state-controlled firms with higher debt could exhibit lower conditional eonservatism. 
In firms with low or no debt, the debt demand for conservatism will cease to play the dominant role and the demand for conditional conservatism could come from other sources such as equity holders. According to investor attraction perspective, the shareholders should process gains and losses asymmetrically and they dislike future disappointments. Therefore shareholders can demand for conditional conservatism in state-controlled firms. Not According to the agency view, no matter whether firms are equity financed from the stock market or self-financed from internally generated capital [4], there is a need from shareholders for conditional conservatism in state-controlled firms where managers have a motivation to deliberately overstate their profits in order to meet targets and receive bonuses (Liao, 1989). Therefore the use of conservative accounting policies in Chinese state-controlled firms has been encouraged in recent years (Ezzamel et al., 2007). In summary, the first hypothesis is as follows:

H1: State-controlled firms with different levels of debt exhibit different levels of conditional accounting conservatism.

AAs the government is the controlling shareholder and a provider of security, the default probability is inherently lower in state-controlled firms rather than other organizational structures. Moreover, state-controlled banks have a political objective to financially support state-controlled firms (Chen et al., 2010), which further protects creditors from losses caused by potential default. Therefore, the debt demand for conditional conservatism in state-controlled firms is generally lower than other forms of firm ownership. In state-controlled firms with high leverage, the low debt demand for conditional conservatism could dominate the equity demand for conditional conservatism. Therefore, state-controlled firms with higher leverage would exhibit low conditional conservatism as a whole. In contrast, in state-controlled firms with low or zero 
leverage, the equity demand plays the dominant role and these firms could exhibit high conditional conservatism. In summary, the equity demand for conditional accounting conservatism is more prominent in state-controlled firms with low or zero leverage. Therefore the first hypothesis is as follows:

\section{H1: State-controlled firms with low or zero leverage exhibit more conditional accounting} $\underline{\text { conservatism. }}$

As the controlling shareholder in state-controlled firms, the government obtains economic interests through their shareholdings. There can be agency conflicts between managers and the controlling shareholder in state-controlled firms; and these costs might be high for firms with high government share-holding. Accounting conservatism has been encouraged by regulators (Ezzamel et al., 2007), because it is an effective tool to protect long-term interests of shareholders, the controlling shareholder in particular, and to help address market uncertainty and improve the reliability of accounting information, and benefits controlling shareholder/government (Li, 2001).

In addition, in firms with controlling shareholders, the risk of expropriation of minority shareholders could discourage the participation of small investors. For state-controlled firms, large profits could easily draw the attention from the public and may undergo political scrutiny. Therefore, in order to protect the interests of minority shareholders and avoid the potential political costs, the demand for conditional conservatism is higher in state-controlled firms with a higher government controlling stake. Therefore, the second hypothesis is as follows: 
H2: State-controlled firms with high government control stake exhibit more conditional accounting conservatism.

\section{Research Design}

\subsection{Measure of accounting conservatism}

The timeliness of earnings to news (Basu, 1997) is used as the measure of conditional accounting conservatism. This examines the extent of timeliness to which accounting income responds to good news (proxied by positive stock returns) versus bad news (proxied by negative stock returns). The piecewise linear regression is specified in Equation (1). The asymmetric recognition of bad news relative to good news is captured by a positive $\beta_{3}$, the coefficient on $D R_{i t} * R_{i t}$

$$
N I_{i t}=\beta_{0}+\beta_{1} D R_{i t}+\beta_{2} R_{i t}+\beta_{3} D R_{i t} * R_{i t}+\varepsilon
$$

where subscripts $i$ and $t$ stand for firm and year respectively. $N I_{i t}$ is the net income before extraordinary items for firm $i$ and year $t$ deflated by the beginning-of-year market value, $R_{i t}$ is the stock return for firm $i$ over the fiscal year $t$, and $D R_{i t}$ is a dummy variable that equals 1 if $R_{i t}$ is less than zero, and 0 otherwise.

\subsection{Sample and data}

The sample in this study selects state-controlled firms listed in HKSE instead of firms listed in Mainland China out of the following consideration/motivation. This study attempts to explore the equity demand for conditional conservatism in state-controlled firms. The relatively underdeveloped stock market in Mainland China could blur the relationship between equity demand 
and conservatism in state-controlled firms. In addition, Hong Kong is in line with developed countries in terms of legal system, accounting standards and economy and market development. This is important because the return-based timely loss recognition measures assume market efficiency (Dechow et al., 2010). According to the criteria proposed by La Porta et al. (1998), Hong Kong law is in the common law family and Hong Kong scores five out of six in the shareholder rights measures; the financial market, the corporate governance practice and accounting standards in Hong Kong are at a development level comparable to developed economies (Cheung et al., 2007).

The initial sample starts with the firms listed on the Main Board of Hong Kong Stock Exchange (HKSE). These firms are ranked from high to low according to the market capitalization and the ultimate control data is hand collected for 312 industrial firms excluding financial and utility firms. The firm's ultimate controlling shareholder (controlling shareholder hereafter) is defined as the largest shareholder in the control chain with the absolute majority of voting rights and at least five percent of the ultimate control rights (La Porta et al., 1999). A firm is defined as state-controlled if the ultimate controlling shareholder is the government. Finally, 87 out of 312 firms are identified as state-controlled firms.

The sample period is from 1997 to 2013 . Before 1997, not many state-controlled firms were listed in Hong Kong. Claessens et al. (2000) find only 3\% of firms are state-controlled in their sample of 330 firms listed in HKSE as of the end of 1996 or the closest date. However after this date with further opening up of China regulations and deepening reforms, more and more state-controlled firms from Mainland China get listed in HKSE. In 2014, the Chinese 
government launched the Shanghai-Hong Kong Stock Connect program. This program for the first time allows the Mainland China investors (Hong Kong investors) to directly trade shares listed on HKSE (Shanghai Stock Exchange) and dramatically changed the stock return pattern in both markets. Hence the sample period ends in 2013 to avoid the effect of this program on the return-based conditional conservatism measure.

Firm-year observations with missing data are deleted. To eliminate the effect of outliers, the independent, dependent and control variables are winsorized at the $1 \%$ level. This leaves 849 firm-year observations for state-controlled firms. In some of the tests, the numbers of observations are reduced due to different data requirements.

\section{Data Analysis}

\subsection{Preliminary result}

To test Hypothesis 1, leverage is used to measure the level of debt and is defined as debt divided by total assets at the end of the year $t-1$. Following the methodology in Louis and Urcan (2015), firms are split into a high leverage group where the leverage is higher than $15.8 \%$ (median of all firms in our sample), a low leverage group where the leverage of firms is below $15.8 \%$, a very low leverage group where the leverage of firms is below $3 \%$ (the $5^{\text {th }}$ percentile of all firms in our sample), and a zero leverage group where the leverage of firms is zero.

Table 1 presents the regression results for high leverage, low leverage, very low leverage and zero leverage firms in Panel A, Panel B, Panel C and Panel D respectively. The coefficient 
on $D R^{*} R$ in state-controlled firms is insignificantly positive $(0.038)$ for high leverage firms, insignificantly positive (0.060) for low leverage firms, but is significantly positive $(0.136)$ at the $10 \%$ level for very low leverage firms, and is significantly positive $(0.312)$ at the $5 \%$ level for zero leverage firms. Lower conditional conservatism in high leverage firms indicates the dominant role of the debt demand for conditional conservatism, but the higher conditional conservatism in very low and zero leverage firms are mainly attributable to other factors such as equity demand because debt demand is low or zero. These results showing a difference in the level of conditional conservatism based on the leverage levels provides support for the first hypothesis (H1).

\section{$<$ Insert Table 1 here $>$}

To test Hypothesis 2, the sample of state-controlled firms is split based on their control rights. High control firms refer to the firms that have control rights greater than $62 \%$ (the top quartile) and low control firms refer to the firms that have control rights lower than $41 \%$ (the bottom quartile). Panel A of Table 2 compares the descriptive statistics of high control firms versus low control firms. High control firms are more negatively skewed in earnings, lower in leverage, younger in establishment date and tend to pay higher dividends. Panel B of Table 2 presents Pearson correlation coefficients of main variables. Some of the correlations are above 0.2. This suggests possible interaction effect and justifies the multi-variant analysis below.

$<$ Insert Table 2 here $>$ 
Table 3 Panel A presents the regression results from the following model [5].

$$
\begin{aligned}
N I_{i t} & =\beta_{0}+\beta_{1} D R_{i t}+\beta_{2} R_{i t}+\beta_{3} D R_{i t} * R_{i t}+\beta_{4} \operatorname{HighCon}_{i t}+\beta_{5} \operatorname{HighCon}_{i t} * D R_{i t} \\
& +\beta_{6} \operatorname{HighCon}_{i t} * R_{i t}+\beta_{7} \operatorname{HighCon}_{i t} * D R_{i t} * R_{i t}+\varepsilon
\end{aligned}
$$

where HighCon $_{i t}$ is a dummy variable that equals 1 if firm $i$ that has control rights greater than $62 \%$, and 0 if firm $i$ have control rights lower than $41 \%$. The coefficient on $\operatorname{HighCon}_{i t}{ }^{*} D R_{i t}{ }^{*} R_{\text {it }}$ in Table 3 is positive $(0.175)$ and significant at the $10 \%$ level, providing some weak evidence that state-controlled firms with high control rights are more conservative than firms with low control rights. This provides some support for Hypothesis 2.

$<$ Insert Table 3 here $>$

\subsection{Multi-variable analysis}

Firstly, as elaborated above, the declining debt demand for conditional conservatism in firms with decreasing level of leverage is shown in Table 1. If high control stake implies high equity demand for conditional conservatism, it is interesting to see how control stake and leverage jointly affect the conditional conservatism in state-controlled firms.

Secondly, in the reform process of state-controlled firms, radical changes have occurred in terms of the role and functions of government and accounting conservatism. The role of government in these firms changes from economy planner, capital provider, and profit distributor to a controlling shareholder. Along with the role of government changes, accounting conservatism, originally viewed as a means of deliberately understating profits (Xin and Huang, 
1951) and later allowed in Chinese-foreign joint-ventures for harmonizing international accounting practice (Ge et al., 1988), and-was encouraged in these firms (Ezzamel et al., 2007).

However, the historical environment can have an impact on firm behavior. For example, CEOs who grew up during the Great Depression are averse to debt and prefer to use internal finance and CEOs with military experience pursue more aggressive policies, including higher leverage (Malmendier et al., 2011). Also Ezzamel et al. (2007) suggest that “...dominant political ideology creates a context that can discourage, but never forecloses, the scope for debate on alternative accounting practices because elements are never fully transformed into moments with fixed meanings". Therefore, the different speed at which firms react to these changes could induce different conditional conservatism in state-controlled firms. For example, the year of 1992 is a critical time point in the transformation of institutional environment facing statecontrolled firms, as in that year an important political and legal document, the Accounting System for Companies Experimenting with Shareholding System, was issued (Ministry of Finance, 1992). From this time on, the government became the major shareholder of statecontrolled firms and minority shareholders were legally treated as a contributor of finance to a firm and had legal rights to share in the profit of the firm.

In addition, firms incorporated before 1992 are older than firms incorporated after 1992. Facing changes such as pursuit of innovation, business/industry growth and regulatory change, old firms usually tend to be slower in response, take longer transition period and incur higher cost (Jovanovic, 1982; Pakes and Ericson, 1998). Therefore the firm objectives, culture and style of management of state-controlled firms established before 1992 would be different from those firms established after 1992. This could lead to differences in conditional conservatism. 
Thirdly, various corporate governance tools can substitute for each other. Although high control rights held by controlling shareholders can be effective in aligning the interests between managers and shareholders, dividend payments can also serve as an important tool in disciplining management and controlling agency costs (Easterbrook, 1984). Louis and Urcan (2015) find a negative relation between dividend payments and accounting conservatism.

To examine the joint effects of leverage, establishment date and dividends with control rights, the following model (3) is estimated:

$$
\begin{aligned}
N I_{i t}= & \beta_{0}+\beta_{1} D R_{i t}+\beta_{2} R_{i t}+\beta_{3} D R_{i t} * R_{i t}+\beta_{4} \text { HighCon }_{i t}+\beta_{5} \text { HighCon }_{i t} * D R_{i t} \\
& +\beta_{6} \text { HighCon }_{i t} * R_{i t}+\beta_{7} \text { HighCon }_{i t} * D R_{i t} * R_{i t}+\beta_{8} X_{i t}+\beta_{9} X_{i t} * D R_{i t} \\
& +\beta_{10} X_{i t} * R_{i t}+\beta_{11} X_{i t} * D R_{i t} * R_{i t}+\varepsilon
\end{aligned}
$$

where $X_{i t}$ is alternatively each of the three variables Lev $v_{i t}$, Young $_{i t}$ and $D i v_{i t}$. Div $v_{i t}$ is debt divided by total assets at the end of the year $t-1$. Young $_{i t}$ is a dummy variable that is 1 if a firm is incorporated after 1992 and 0 otherwise; Div $v_{i t}$ is a proxy for dividends payment measured as total dividends divided by total assets; and all other variables are defined as before. A positive $\beta_{7}$, the coefficient on $\operatorname{HighCon}_{i t}{ }^{*} D R_{i t} * R_{i t}$, would indicate higher conditional conservatism in statecontrolled firms with high control rights than in firms with low control rights. A positive $\beta_{11}$, the coefficient on $X_{i t}{ }^{*} D R_{i t} * R_{i t}$, would indicate that the factor measured by $X_{i t}$ is positively associated with conditional conservatism.

Table 3 Panel B shows the joint effect of control rights and leverage. The coefficient on $\operatorname{HighCon}_{i t} * D R_{i t} * R_{i t}$, remains positive (0.180) and the significance increases to $5 \%$ level; and the coefficient on $\operatorname{Lev}_{i t} * D R_{i t} * R_{i t}$, is negative (-0.451) and significant at the $10 \%$ level. This suggests the offsetting effect of control right and leverage on conditional conservatism. Even though the 
debt demand for conditional conservatism is low, the demand from the high control stakeholders (government) induces conditional conservatism in state-controlled firms.

Table 3 Panel $\mathrm{C}$ shows the joint effect of control rights and the year the firm was incorporated. The coefficient on $\operatorname{HighCon}_{i t}{ }^{*} D R_{i t} * R_{i t}$, remains positive (0.138) and the significance increases to $5 \%$ level; and the coefficient on $Y_{o u n g}{ }_{i t} D R_{i t} * R_{i t}$, is also positive $(0.218)$ and significant at the $10 \%$ level. This suggests a reinforcing effect of control right and year of incorporation after 1992 on conditional conservatism as the demand for conditional conservatism is even higher in state-controlled firms incorporated after 1992.

Table 3 Panel D shows the joint effect of control rights and dividends payment. The coefficient on $\operatorname{HighCon}_{i t}{ }^{*} D R_{i t} * R_{i t}$, remains positive (0.204) and the significance increases to $5 \%$ level; and the coefficient on $D i v_{i t}{ }^{*} D R_{i t} * R_{i t}$, is negative (-2.781) and significant at the $10 \%$ level. This suggests a substituting effect of control right and dividends on conditional conservatism. High dividend payment serves as a corporate governance tool and reduces the demand for conditional conservatism and the demand for conditional conservatism from high control remains high.

\subsection{Additional analysis}

The analysis below incorporates all variables into one model and the specification of the model (4) is as follows: 


$$
\begin{aligned}
N I_{i t}= & \beta_{0}+\beta_{1} \text { DR }_{i t}+\beta_{2} R_{i t}+\beta_{3} \text { DR }_{i t} * R_{i t}+\beta_{4} \text { HighCon }_{i t}+\beta_{5} \text { HighCon }_{i t} * D R_{i t} \\
& +\beta_{6} \text { HighCon }_{i t} * R_{i t}+\beta_{7} \text { HighCon }_{i t} * D R_{i t} * R_{i t}+\beta_{9} \text { Lev }_{i t}+\beta_{10} \text { Lev }_{i t} * D R_{i t} \\
& +\beta_{11} \text { Lev }_{i t} * R_{i t}+\beta_{12} \text { Lev }_{i t} * D R_{i t} * R_{i t}+\beta_{13} \text { Young }_{i t}+\beta_{14} \text { Young }_{i t} * D R_{i t} \\
& +\beta_{15} \text { Young }_{i t} * R_{i t}+\beta_{16} \text { Young }_{i t} * D R_{i t} * R_{i t}+\beta_{17} \text { Div }_{i t}+\beta_{18} \text { Div }_{i t} * D R_{i t} \\
& +\beta_{19} \text { Div }_{i t} * R_{i t}+\beta_{20} \text { Div }_{i t} * D R_{i t} * R_{i t}+\beta_{21} \text { Size }_{i t}+\beta_{22} \text { Size }_{i t} * D R_{i t} \\
& +\beta_{23} \text { Size }_{i t} * R_{i t}+\beta_{24} \text { Size }_{i t} * D R_{i t} * R_{i t}+\beta_{25} M B_{i t}+\beta_{26} M B_{i t} * D R_{i t} \\
& +\beta_{27} M B_{i t} * R_{i t}+\beta_{28} M B_{i t} * D R_{i t} * R_{i t} \varepsilon
\end{aligned}
$$

where $S I Z E_{i t}$ is the natural $\log$ of total assets at the end of year $t-1 ; M B_{i t}$ is calculated as the market value of equity divided by the book value of equity at the end of year $t-1$; and all other variables are defined as before.

Table 4 reports the estimates from equation (4). Model 1 examines the joint effect of the variables of HighCon $i$, Lev $i t$, Young $i t$ and Divit; and Model 2 the joint effect of all the variables including $S_{i z} e_{i t}$ and $M B_{i t}$ ratio. In both models, the coefficient on $\operatorname{HighCon}_{i t}{ }^{*} D R_{i t} * R_{i t}$, remains positive and the significance increases to $1 \%$ level; and the coefficient on other variables become less significant. This indicates the demand for conditional conservatism from high control rights is dominant and the effect of other variables is reduced.

$<$ Insert Table 4 here $>$

\section{Conclusions}

This study explores the demand for conditional accounting conservatism from equity investors in state-controlled firms. If leverage proxies for debt pressure for conditional conservatism, then low or zero leverage indicates low or no debt demand for conditional conservatism. Following the methodology in the study by Louis and Urcan (2015), state-controlled firms are divided into 
subgroups according to different leverage levels. State-controlled firms with high leverage exhibits no conditional conservatism but firms with low and zero leverage exhibits higher levels of conditional conservatism [6].

Further analysis explores possible factors that induce conditional conservatism in statecontrolled firms. The controlling shareholders with high control rights are considered as an important source of equity demand for conditional conservatism in low and zero leverage firms. This hypothesis is supported by the positive association between high control rights and conditional conservatism in the timeliness of earnings to news model.

To examine whether important firm level variables in addition to control rights are associated with incrementally significant effects on conditional conservatism, separate analyses are conducted on the joint effect of high control rights, leverage, year of incorporation before or after 1992 and dividend payments on conditional conservatism. The results show an offsetting effect between high control and leverage, a reinforcing effect between high control and year of incorporation after 1992, and a substituting effect between high control rights and dividend payments. In all results, including incorporating all variables into one model, high control rights remain significantly positive. This is consistent with the hypothesis suggesting the demand from equity shareholders with high control can be an important source inducing conditional conservatism in state-controlled firms.

Finally, this study notes some limitations. This study is exploratory in nature and is not intended to establish causality between variables. The timeliness of earnings to news model (Basu, 1997) is used as a measure of conditional conservatism because this measure is relevant to 
the purpose of this study or the equity demand for conservatism, but it has well-documented limitations (Kahn Khan and Watts, 2009; Ball et al., 2013). Although this study discusses the effect of some important firm level variables on conditional conservatism, there are certainly other omitted variables including for example, CG-scores. All of these concerns deserve further research. 


\section{References}

Ball, R., Kothari, S. P., Nikolaev, V. (2013) "Econometrics of the Basu asymmetric timeliness coefficient and accounting conservatism." Journal of Accounting Research $51,1071-1097$.

Ball, R., Robin, A., Sadka, G. (2008). “Is financial reporting shaped by equity markets or by debt markets? An international study of timeliness and conservatism". Review of Accounting Studies 13, 168-205.

Basu, S. (1997). "The conservatism principle and the asymmetric timeliness of earnings". Journal of Accounting and Economics 24, 3-37.

Chen, H., Chen, J. Z., Lobo, G. J., Wang, Y. (2010). “Association between borrower and lender state ownership and accounting conservatism”. Journal of Accounting Research 48, 973-1014.

Cheung, Y. L., Connelly, J. T., Limpaphayom, P., Zhou, L. (2007). "Do investors really value corporate governance? Evidence from the Hong Kong market”. Journal of International Financial Management and Accounting 18, 86-121.

Claessens, S., Djankov, S., Lang, L. H. P. (2000). "The separation of ownership and control in East Asian corporations". Journal of Financial Economics 58, 81-112.

Dechow, P., Ge, W., Schrand, C. (2010). "Understanding earnings quality: A review of the proxies, their determinants and their consequences". Journal of Accounting and Economics 50, 344-401. 
Dickhaut, J., Basu, S., McCabe, K., Waymire, G. (2010). "Neuroaccounting: Consilience between the biologically evolved brain and culturally evolved accounting principles". Accounting Horizons 24, 221-255.

Easterbrook, F. (1984). "Two agency-cost explanations of dividends". American Economic Review 74, 650-659.

Ezzamel, M., Xiao, J. Z., Pan, A. (2007). "Political ideology and accounting regulation in China”. Accounting, Organizations and Society 32, 669-700.

Garcia Lara, J., Garcia Osma, B., Penalva, F. (2009). “The economic determinants of conditional conservatism". Journal of Business Finance and Accounting 36, 336-372.

Ge, J. S., Lin, Z. J., Wei, M. H. (1988). "Application of conservatism to the accounting system for firms using foreign investment". Accounting Research 5, 19-22. Hirshleifer, D., Teoh, S. H. (2009). "The psychological attraction approach to accounting and disclosure policy". Contemporary Accounting Research 26, 1067 1190.

Hong Kong Institute of Directors ("HKIoD") (2012). "Survey finds significant improvement in corporate governance among Hong Kong-listed companies". $\underline{\text { http://www.hkiod.com }}$

Jovanovic, B. (1982), "Selection and the evolution of industry", Econometrica 50, 649-670.

Khan, M., Watts, R. (2009). "Estimation and empirical properties of a firm-year measure of accounting conservatism." Journal of Accounting and Economics 48, 132 150. 
Lafond, R., Roychowdhury, S. (2008). "Managerial ownership and accounting conservatism”. Journal of Accounting Research 46, 101-135.

La Porta, R., Lopez-de-Silanes, F., Shleifer, A., Vishny, R. W. (1998). "Law and finance”. Journal of Political Economy 106, 1113-1155.

La Porta, R., Lopez-de-Silanes, F., Shleifer, A. (1999). “Corporate ownership around the world". Journal of Finance 44, 471-517.

Li, Y. (2001). A major measure for developing an accounting system suitable for China - The issue of the Enterprise Accounting System. China Finance and Economics Newspaper. <http://www.e521.com/cksj/yjyw/0036.htm>.

Liao, C. J. (1989). "Personal views on the application of conservatism". Yunnan Accounting 5, 26-28.

Louis, H., Sun, A., Urcan, O. (2012). "Value of cash holdings and accounting conservatism”. Cotemporary Accounting Research 29, 1249-1271.

Louis, H., Urcan, O. (2015). "Agency conflicts, dividend payout, and the direct benefits of conservative financial reporting to equity holders". Contemporary Accounting Research 32, 455-484.

Malmendier, U., Tate, G., Yan, J. (2011). “Overconfidence and early-life experiences: The effect of managerial traits on corporate financial policies". Journal of Finance 66, $1687-1733$.

Ministry of Finance (1992). Accounting system for experimental shareholding enterprises. Beijing, China: The Ministry of Finance. 
Nikolaev, V. (2010). "Debt covenants and accounting conservatism." Journal of Accounting Research 48, 51-89.

Pakes, A. and R. Ericson (1998), "Empirical Implications of Alternative Models of Firm Dynamics", Journal of Economic Theory 79, 1-45.

Petersen, M. A. (2009). "Estimating standard errors in finance panel data sets: Comparing approaches". Review of Financial Studies 22, 435-480.

Shleifer, A. (1998). "State versus private ownership". Journal of Economic Perspectives 12, 133-150.

Xin, Z., Huang, S. (1951). "How to construct new China's theoretical accounting basis". New Accounting 1, 12-16.

Watts, R. (2003). “Conservatism in accounting, Part I: Explanations and implications”. Accounting Horizons 17, 207-221. 
Notes:

[1] Basu (1997) defines conditional conservatism as a "higher degree of verification to recognize good news as gains than to recognize bad news as losses."

[2] Watts (2003) suggests that “conservatism benefits users of the firm's accounting reports. One explanation is that conservatism arises because it is part of the efficient technology employed in the organization of the firm and its contracts with various parties. Under this contracting explanation, conservative accounting is a means of addressing moral hazard caused by parties to the firm having asymmetric information, asymmetric payoffs, limited horizons, and limited liability. For example, conservatism can contain management's opportunistic behavior in reporting accounting measures used in a contract".

[3] The Shanghai-Hong Kong Stock Connect program has been expected to narrow the price differences for shares of Chinese companies listed in the Shanghai Stock Exchange (A shares) and in the Hong Kong Stock Exchange (H shares). The price differences between the $\mathrm{A}$ and $\mathrm{H}$ shares narrowed significantly over the third quarter of 2014 (BIS Quarterly Review, December 2014). http://www.bis.org/publ/qtrpdf/r_qt1412u.htm).

[4] Self-financing could lead to less efficient use of internal capital and increase the agency conflicts between manager and shareholders. Louis et al. (2012) find accounting conservatism can mitigate the value destruction associated with cash holdings.

[5] In the estimation of equation 2 and equation 3, the cluster-robust error estimation controls both time fixed effect and firm fixed effect (Petersen, 2009).

[6] For comparison, the same analysis is also conducted on a sample of familycontrolled firms listed in HKSE (see the tableTable A in Appendix). There is no substantial difference in the conditional conservatism between groups with different leverage levels. Or in contrary to the findings on state-controlled firms, the variation in conditional conservatism in different leverage groups is not found in familycontrolled firms. 
Table 1: Regression analysis for state-controlled firms with different leverage levels

\begin{tabular}{|c|c|c|}
\hline Panel A: (firms with leverage above median $15.8 \%$ ) & \multicolumn{2}{|c|}{ Dependent Variable: NI } \\
\hline Independent Variable & Coefficient & $\mathrm{t}$-value \\
\hline INTERCEPT & $0.064 * *$ & 2.39 \\
\hline$D R$ & -0.037 & -1.59 \\
\hline$R$ & 0.034 & 1.21 \\
\hline$D R * R$ & 0.038 & 0.52 \\
\hline Adj. $R^{2}(\%)$ & 6.4 & \\
\hline Obs. & 484 & \\
\hline Panel B: (firms with leverage below median15.8\%) & \multicolumn{2}{|c|}{ Dependent Variable: NI } \\
\hline Independent Variable & Coefficient & $\mathrm{t}$-value \\
\hline INTERCEPT & $0.078 * * *$ & 6.75 \\
\hline$D R$ & -0.004 & -0.24 \\
\hline$R$ & $0.033^{* *}$ & 2.18 \\
\hline$D R * R$ & 0.060 & 1.55 \\
\hline Adj. $R^{2}(\%)$ & 9.8 & \\
\hline Obs. & 365 & \\
\hline Panel C: (firms with leverage below 3\%) & \multicolumn{2}{|c|}{ Dependent Variable: NI } \\
\hline Independent Variable & Coefficient & $\mathrm{t}$-value \\
\hline INTERCEPT & $0.080 * * *$ & 5.51 \\
\hline$D R$ & 0.016 & 0.67 \\
\hline$R$ & 0.005 & 0.23 \\
\hline$D R * R$ & $0.136^{*}$ & 2.00 \\
\hline Adj. $R^{2}(\%)$ & 7.1 & \\
\hline Obs. & 123 & \\
\hline Panel D: (firms with zero leverage) & \multicolumn{2}{|c|}{ Dependent Variable: NI } \\
\hline Independent Variable & Coefficient & $\mathrm{t}$-value \\
\hline INTERCEPT & $0.075^{* * *}$ & 4.21 \\
\hline$D R$ & 0.038 & 1.17 \\
\hline$R$ & -0.059 & -1.30 \\
\hline$D R * R$ & $0.312 * *$ & 2.55 \\
\hline Adj. $R^{2}(\%)$ & 24.3 & \\
\hline Obs. & 53 & \\
\hline
\end{tabular}

Table 1 presents estimates of conditional accounting conservatism in state-controlled firms with different leverage levels using the following regression model:

$N I_{i t}=\beta_{0}+\beta_{1} D R_{i t}+\beta_{2} R_{i t}+\beta_{3} D R_{i t} * R_{i t}+\varepsilon$

$N I_{i t}$ is the net income before extraordinary items for firm $i$ and year $t$ deflated by market value in year $t-1 . R_{i t}$ is the stock return for firm $i$ in year $t . D R_{i t}$ is a dummy variable that equals 1 if $R_{i t}$ is less than zero, and 0 otherwise. The sample period is from 1997 to 2013. The t-statistics are based on cluster-robust standard errors controlling for year fixed effect and firm fixed effect. ***,** and * indicate significance at the $1 \%, 5 \%$ and $10 \%$ levels respectively. 
Table 2: Descriptive statistics (high control vs. low control firms)

\begin{tabular}{|c|c|c|c|c|c|c|c|c|c|}
\hline \multirow{2}{*}{$\begin{array}{l}\text { Panel A: } \\
\text { variable }\end{array}$} & \multirow[b]{2}{*}{ Obs. } & \multicolumn{2}{|c|}{ High Control } & \multicolumn{6}{|c|}{ Low Control } \\
\hline & & Mean & $\begin{array}{l}\text { Std. } \\
\text { Dev }\end{array}$ & Median & Obs. & Mean & $\begin{array}{l}\text { Std. } \\
\text { Dev }\end{array}$ & Median & $\begin{array}{l}\text { t-test } \\
\text { p-value }\end{array}$ \\
\hline Control & 191 & 0.707 & 0.064 & 0.699 & 184 & 0.313 & 0.091 & 0.338 & $<.0001$ \\
\hline$N I$ & 191 & 0.087 & 0.099 & 0.088 & 184 & 0.066 & 0.119 & 0.060 & 0.07 \\
\hline$R$ & 191 & 0.265 & 0.588 & 0.115 & 184 & 0.256 & 0.777 & 0.076 & 0.90 \\
\hline$L E V$ & 191 & 0.174 & 0.116 & 0.159 & 184 & 0.209 & 0.149 & 0.202 & 0.01 \\
\hline Young & 191 & 0.921 & 0.270 & 1.000 & 184 & 0.690 & 0.464 & 1.000 & $<0.0001$ \\
\hline$D I V$ & 164 & 0.023 & 0.021 & 0.017 & 149 & 0.015 & 0.020 & 0.008 & 0.0005 \\
\hline SIZE & 191 & 23.979 & 1.847 & 23.814 & 184 & 22.818 & 1.450 & 22.741 & $<0.0001$ \\
\hline$M B$ & 191 & 1.903 & 1.570 & 1.588 & 184 & 2.302 & 2.195 & 1.500 & 0.04 \\
\hline \multicolumn{10}{|c|}{ Panel B: Correlation } \\
\hline & Control & $N I$ & $R$ & $L E V$ & Young & $D I V$ & SIZE & $M B$ & \\
\hline \multicolumn{10}{|l|}{ Control } \\
\hline$N I$ & $0.10^{*}$ & & & & & & & & \\
\hline$R$ & 0.02 & $0.35^{* * *}$ & & & & & & & \\
\hline$L E V$ & -0.06 & $-0.11^{* *}$ & 0.03 & & & & & & \\
\hline Young & $0.25^{* * *}$ & $0.14^{* * *}$ & -0.02 & -0.05 & & & & & \\
\hline$D I V$ & $0.15 * * *$ & 0.03 & -0.02 & $-0.16 * * *$ & $0.11^{* *}$ & & & & \\
\hline SIZE & $0.26^{* * *}$ & $0.14 * * *$ & -0.08 & $0.16 * * *$ & $0.22 *$ & $0.36 * * *$ & & & \\
\hline$M B$ & $-0.13 * *$ & -0.02 & -0.06 & $-0.14 * * *$ & $0.17 *$ & $0.20 * * *$ & $0.13 * *$ & & \\
\hline
\end{tabular}

The sample of state-controlled firms is split based on their control rights. High control firms refer to the firms that have control rights greater than $62 \%$ (the top quartile). Low control firms refer to the firms that have control rights lower than $41 \%$ (the bottom quartile). Table 2 presents the descriptive statistics of the main variables and control variables in the high control vs. low control firms. Control is ultimate control rights held by the largest shareholder or the government. Lev is debt divided by total assets at the end of the year t-1. Young is a dummy variable that is 1 if a firm is incorporated after 1992 and 0 otherwise. Div is a proxy for dividends payment measured as total dividends divided by total assets. SIZE is the natural log of total assets at the end of year $t-1$. LEV is debt divided by total assets at the end of the year $t-1 . M B$ is calculated as the market value of equity divided by the book value of equity at the end of year $t-1$. All other variables are defined as before. 
Table 3: Regression analysis in high control firms vs. low control firms

\begin{tabular}{|c|c|c|}
\hline Panel A: (high control vs. low control) & \multicolumn{2}{|c|}{ Dependent Variable: NI } \\
\hline Independent Variable & Coefficient & t-value \\
\hline INTERCEPT & $0.074 * * *$ & 4.07 \\
\hline$D R$ & -0.053 & -1.52 \\
\hline$R$ & $0.037^{*}$ & 1.98 \\
\hline$D R * R$ & -0.044 & -0.6 \\
\hline HighCon & 0.006 & 0.31 \\
\hline $\operatorname{HighCon} * D R$ & $0.064 *$ & 1.72 \\
\hline $\operatorname{HighCon} * R$ & 0.012 & 0.5 \\
\hline $\operatorname{HighCon} * D R * R$ & $0.175^{*}$ & 2 \\
\hline Adj. $R^{2}(\%)$ & 15.2 & \\
\hline Observations & 375 & \\
\hline Panel B: (control and leverage) & \multicolumn{2}{|c|}{ Dependent Variable: NI } \\
\hline Independent Variable & Coefficient & t-value \\
\hline INTERCEPT & $0.086^{* * *}$ & 3.64 \\
\hline$D R$ & -0.005 & -0.12 \\
\hline$R$ & 0.016 & 0.67 \\
\hline$D R * R$ & 0.022 & 0.31 \\
\hline HighCon & 0.007 & 0.33 \\
\hline $\operatorname{HighCon} * D R$ & $0.064 *$ & 1.94 \\
\hline $\operatorname{HighCon} * R$ & 0.012 & 0.49 \\
\hline $\operatorname{HighCon} * D R * R$ & $0.180 * *$ & 2.09 \\
\hline Lev & -0.062 & -0.68 \\
\hline$L e v * D R$ & -0.278 & -1.65 \\
\hline$L e v^{*} R$ & 0.101 & 1.08 \\
\hline$L e v * D R * R$ & $-0.451^{*}$ & -1.74 \\
\hline Adj. $R^{2}(\%)$ & 19.1 & \\
\hline Observations & 375 & \\
\hline Panel C: (control and establishment year) & \multicolumn{2}{|c|}{ Dependent Variable: NI } \\
\hline Independent Variable & Coefficient & t-value \\
\hline INTERCEPT & $0.064 *$ & 1.76 \\
\hline$D R$ & $-0.132 *$ & -1.93 \\
\hline$R$ & 0.021 & 0.64 \\
\hline$D R * R$ & -0.204 & -1.52 \\
\hline HighCon & 0.009 & 0.44 \\
\hline $\operatorname{HighCon} * D R$ & 0.032 & 1.16 \\
\hline $\operatorname{HighCon} * R$ & -0.001 & -0.08 \\
\hline $\operatorname{HighCon} * D R * R$ & $0.138 * *$ & 2.51 \\
\hline Young & 0.009 & 0.24 \\
\hline Young ${ }^{*} D R$ & 0.117 & 1.65 \\
\hline Young $* R$ & 0.032 & 1.02 \\
\hline Young $* D R * R$ & $0.218^{*}$ & 1.75 \\
\hline Adj. $R^{2}(\%)$ & 18.2 & \\
\hline Observations & 375 & \\
\hline Panel D: (control and dividends) & \multicolumn{2}{|c|}{ Dependent Variable: NI } \\
\hline Independent Variable & Coefficient & t-value \\
\hline INTERCEPT & $0.076^{* * *}$ & 3.82 \\
\hline$D R$ & -0.067 & -1.62 \\
\hline$R$ & $0.037 *$ & 1.84 \\
\hline$D R * R$ & -0.040 & -0.49 \\
\hline HighCon & 0.008 & 0.38 \\
\hline
\end{tabular}




\begin{tabular}{lcc}
\hline HighCon $^{*} D R$ & $0.066^{*}$ & 1.91 \\
HighCon $^{*} R$ & 0.012 & 0.49 \\
HighCon $^{*} D R^{*} R$ & $0.204^{* *}$ & 2.4 \\
$\operatorname{Div}^{*}$ & -0.064 & -0.42 \\
$\operatorname{Div}^{*} D R$ & 0.424 & 0.58 \\
$\operatorname{Div}^{*} R$ & -0.038 & -0.09 \\
$\operatorname{Div}^{*} D R^{*} R$ & $-2.781^{*}$ & -1.8 \\
Adj. $R^{2}(\%)$ & 16.4 & \\
Observations & 369 & \\
\hline
\end{tabular}

Table 3 Panel A presents estimates of accounting conservatism using the following regression model:

$$
\begin{aligned}
N I_{i t}= & \beta_{0}+\beta_{1} D R_{i t}+\beta_{2} R_{i t}+\beta_{3} D R_{i t} * R_{i t}+\beta_{4} H_{i g h C o n}+\beta_{5} H_{i g h C o n} * D R_{i t} \\
& +\beta_{6} H_{i g h C o n} * R_{i t}+\beta_{7} H_{i g h C o n} * D R_{i t} * R_{i t}+\varepsilon
\end{aligned}
$$

where $\mathrm{HighCon}_{i t}$ is a dummy variable that equals 1 if firm $i$ that has control rights greater than $62 \%$, and 0 if firm $i$ have control rights lower than $41 \%$.

Table 3 Panel B, Panel C and Panel D present estimates of accounting conservatism using the following regression model:

$$
\begin{aligned}
N I_{i t}= & \beta_{0}+\beta_{1} D R_{i t}+\beta_{2} R_{i t}+\beta_{3} D R_{i t} * R_{i t}+\beta_{4} H_{i g h C o n}+\beta_{5} H_{i t} C o n \\
& +\beta_{6} H_{i t} * D R_{i t} \text { Con }{ }_{i t} * R_{i t}+\beta_{7} H_{i g h C o n} * D R_{i t} * R_{i t}+\beta_{8} X_{i t}+\beta_{9} X_{i t} * D R_{i t} \\
& +\beta_{10} X_{i t} * R_{i t}+\beta_{11} X_{i t} * D R_{i t} * R_{i t}+\varepsilon
\end{aligned}
$$

where $X_{i t}$ is alternatively Lev $_{i t}$ in Panel B, Young $i t$ in Panel C and Div $v_{i t}$ in Panel D. All other variables are defined as before. The sample period is from 1997 to 2013. The t-statistics are based on cluster-robust standard errors controlling for year fixed effect and firm fixed effect. ***, ** and $*$ indicate significance at the $1 \%, 5 \%$ and $10 \%$ levels respectively. 
Table 4: Additional analysis

\begin{tabular}{|c|c|c|c|c|}
\hline \multicolumn{5}{|c|}{ Dependent Variable: NI } \\
\hline & Model 1 & & Model 2 & \\
\hline Independent & Coefficien & $\mathrm{t}$-value & Coefficien & t-value \\
\hline Variable & $\mathrm{t}$ & & $\mathrm{t}$ & \\
\hline INTERCEPT & $0.077^{*}$ & 1.94 & -0.112 & -0.93 \\
\hline$D R$ & -0.091 & -1.15 & 0.010 & 0.05 \\
\hline$R$ & 0.006 & 0.25 & -0.117 & -0.77 \\
\hline$D R^{*} R$ & -0.161 & -0.89 & 0.864 & 1.05 \\
\hline HighCon & 0.009 & 0.45 & -0.012 & -0.54 \\
\hline HighCon*DR & 0.037 & 1.26 & $0.070^{* *}$ & 2.09 \\
\hline $\operatorname{HighCon} * R$ & -0.001 & -0.04 & 0.000 & -0.02 \\
\hline $\operatorname{HighCon} * D R * R$ & $0.160 * * *$ & 2.77 & $0.255^{* * *}$ & 2.95 \\
\hline Lev & -0.062 & -0.66 & -0.129 & -1.44 \\
\hline$L e v * D R$ & -0.223 & -1.25 & -0.099 & -0.49 \\
\hline$L e v * R$ & 0.081 & 0.72 & 0.090 & 0.93 \\
\hline$L e v * D R * R$ & -0.282 & -1.02 & 0.080 & 0.22 \\
\hline Young & 0.010 & 0.27 & 0.012 & 0.41 \\
\hline Young*DR & 0.108 & 1.61 & $0.106^{*}$ & 1.71 \\
\hline Young*R & 0.028 & 0.78 & 0.025 & 0.73 \\
\hline Young $* D R * R$ & 0.238 & 1.55 & $0.259^{*}$ & 1.82 \\
\hline Div & -0.078 & -0.52 & -0.032 & -0.22 \\
\hline$D i v^{*} D R$ & -0.277 & -0.65 & -0.366 & -0.83 \\
\hline$D i v * R$ & 0.020 & 0.06 & -0.457 & -1.07 \\
\hline$D i v * D R * R$ & $-3.760 * * *$ & -2.78 & -1.775 & -0.86 \\
\hline SIZE & & & 0.010 & 1.61 \\
\hline$S I Z E^{*} D R$ & & & -0.008 & -0.65 \\
\hline$S I Z E^{*} R$ & & & 0.006 & 0.78 \\
\hline$S I Z E^{*} D R * R$ & & & -0.054 & -1.24 \\
\hline$M B$ & & & -0.011 & -1.65 \\
\hline$M B * D R$ & & & $0.018^{* *}$ & 2.45 \\
\hline$M B^{*} R$ & & & 0.000 & 0.03 \\
\hline$M B^{*} D R * R$ & & & 0.016 & 0.83 \\
\hline Adj. $R^{2}$ & 22.1 & & 26.8 & \\
\hline Observations & 369 & & 369 & \\
\hline
\end{tabular}

Table 4 reports the estimates from the following model:

$$
\begin{aligned}
N I_{i t}= & \beta_{0}+\beta_{1} D R_{i t}+\beta_{2} R_{i t}+\beta_{3} D_{i t} * R_{i t}+\beta_{4} \text { HighCon }_{i t}+\beta_{5} \text { HighCon }_{i t} * D R_{i t} \\
& +\beta_{6} \text { HighCon }_{i t} * R_{i t}+\beta_{7} \text { HighCon }_{i t} * D R_{i t} * R_{i t}+\beta_{9} \text { Lev }_{i t}+\beta_{10} \text { Lev }_{i t} * D R_{i t} \\
& +\beta_{11} \text { Lev }_{i t} * R_{i t}+\beta_{12} \text { Lev }_{i t} * D R_{i t} * R_{i t}+\beta_{13} \text { Young }_{i t}+\beta_{14} \text { Young }_{i t} * D R_{i t} \\
& +\beta_{15} \text { Young }_{i t} * R_{i t}+\beta_{16} \text { Young }_{i t} * D R_{i t} * R_{i t}+\beta_{17} \text { Div }_{i t}+\beta_{18} \text { Div }_{i t} * D R_{i t} \\
& +\beta_{19} \text { Div }_{i t} * R_{i t}+\beta_{20} \text { Div }_{i t} * D R_{i t} * R_{i t}+\beta_{21} \text { Size }_{i t}+\beta_{22} \text { Size }_{i t} * D R_{i t} \\
& +\beta_{23} \text { Size }_{i t} * R_{i t}+\beta_{24} \text { Size }_{i t} * D R_{i t} * R_{i t}+\beta_{25} M B_{i t}+\beta_{26} M B_{i t} * D R_{i t} \\
& +\beta_{27} M B_{i t} * R_{i t}+\beta_{28} M B_{i t} * D R_{i t} * R_{i t} \varepsilon
\end{aligned}
$$

Model 1 examines the joint effect of the variables of HighCon $i t$, Lev $_{i t}$, Young $_{i t}$ and Diviti ; and Model 2 the joint effect of all the variables including $S i z e_{i t}$ and $M B_{i t}$ ratio. All variables are defined as before. The sample period is from 1997 to 2013. The t-statistics are based on clusterrobust standard errors controlling for year fixed effect and firm fixed effect. $* * *, * *$ and * indicate significance at the $1 \%, 5 \%$ and $10 \%$ levels respectively. 


\section{Appendix:}

Table A: Regression analysis in family-controlled firms with different leverage levels

\begin{tabular}{lcc}
\hline Panel A: (firms with leverage above median 15.8\%) & \multicolumn{2}{c}{ Dependent Variable: NI } \\
\hline Independent Variable & Coefficient & t-value \\
\hline$I N T E R C E P T$ & $0.088^{* * *}$ & 5.64 \\
$D R$ & $0.046^{* *}$ & 2.07 \\
$R$ & 0.008 & 0.59 \\
$D R^{*} R$ & $0.342^{* * *}$ & 5.25 \\
Adj. $R^{2}(\%)$ & 6.2 & \\
Obs. & 900 \\
\hline Panel B: (firms with leverage below median15.8\%) & Dependent Variable: NI \\
\hline Independent Variable & Coefficient & t-value \\
\hline$I N T E R C E P T$ & $0.099^{* * *}$ & 8.69 \\
$D R$ & 0.016 & 1.07 \\
$R$ & 0.020 & 1.56 \\
$D R * R$ & $0.230^{* * *}$ & 4.39 \\
Adj. $R^{2}(\%)$ & 9.1 & \\
Obs. & 1011 & \\
\hline Panel C: (firms with leverage below 3\%) & Dependent Variable: NI \\
\hline Independent Variable & Coefficient & t-value \\
\hline$I N T E R C E P T$ & $0.060^{* * *}$ & 3.88 \\
$D R$ & $0.042^{* *}$ & 2.20 \\
$R$ & $0.040^{* * *}$ & 3.67 \\
$D R^{*} R$ & $0.208^{* * *}$ & 2.89 \\
Adj. $R^{2}(\%)$ & 10.6 \\
Obs. & 397 \\
\hline Panel D: (firms with zero leverage) & \\
\hline Independent Variable & \multicolumn{2}{c}{397} \\
\hline$I N T E R C E P T$ & Dependent Variable: NI \\
$D R$ & Coefficient & t-value \\
$R$ & $0.053^{* *}$ & 2.55 \\
$D R * R$ & $0.057^{*}$ & 1.77 \\
Adj. $R^{2}(\%)$ & $0.037^{* *}$ & 2.41 \\
Obs. & $0.207^{* * *}$ & 2.75 \\
\hline & 12.6 & \\
\hline & 178 & \\
\hline
\end{tabular}

This table presents estimates of conditional accounting conservatism in family-controlled firms with different leverage levels using the following regression model:

$N I_{i t}=\beta_{0}+\beta_{1} D R_{i t}+\beta_{2} R_{i t}+\beta_{3} D R_{i t} * R_{i t}+\varepsilon$

$N I_{i t}$ is the net income before extraordinary items for firm $i$ and year $t$ deflated by market value in year $t-1 . R$ is the stock return for firm $i$ in year $t . D R_{i t}$ is a dummy variable that equals 1 if $R_{i t}$ is less than zero, and 0 otherwise. The sample period is from 1997 to 2013. The t-statistics are based on cluster-robust standard errors controlling for year fixed effect and firm fixed effect. ***, ** and * indicate significance at the $1 \%, 5 \%$ and $10 \%$ levels respectively. 


\section{Feedback to Reviewer \#2}

We thank the reviewer for the insights and suggestions which have helped us improving the quality of our paper (Manuscript ID ARA-07-2016-0077.R1). Based on the suggestions, we have revised the paper. Below is our feedback to your comments and suggestions (your original comments are in italic).

H1 said that "State-controlled firms with different levels of debt exhibit different levels of conditional accounting conservatism." The argument is not clear. This paper should further focus on the equity demand for conditional conservatism and develop clearly hypotheses.

Thanks for the comments and suggestions. In the revision, we reorganize the argument and rewrite $\mathrm{H} 1$ as follows:

According to investor attraction perspective, shareholders should process gains and losses asymmetrically and they dislike future disappointments. Therefore shareholders can demand for conditional conservatism in state-controlled firms. According to the agency view, no matter whether firms are equity financed from the stock market or self-financed from internally generated capital [4], there is a need from shareholders for conditional conservatism in state-controlled firms where managers have a motivation to deliberately overstate their profits in order to meet targets and receive bonuses (Liao, 1989). Therefore the use of conservative accounting policies in Chinese state-controlled firms has been encouraged in recent years (Ezzamel et al., 2007).

As the government is the controlling shareholder and a provider of security, the default probability is inherently lower in state-controlled firms rather than other organizational structures. Moreover, state-controlled banks have a political objective to financially support state-controlled firms (Chen et al., 2010), which further protects creditors from losses caused by potential default. Therefore, the debt demand for conditional conservatism in state-controlled firms is generally lower than other forms of firm ownership. In state-controlled firms with high leverage, the low debt demand for conditional conservatism could dominate the equity demand for conditional conservatism. Therefore, state-controlled firms with higher leverage would exhibit low conditional conservatism as a whole. In contrast, in state-controlled firms with low or zero leverage, the equity demand plays the dominant role and these firms could exhibit high conditional conservatism. In summary, the equity demand for conditional accounting conservatism is more prominent in state-controlled firms with low or zero leverage. Therefore the first hypothesis is as follows:

H1: State-controlled firms with low or zero leverage exhibit more conditional accounting conservatism. 
In the revised version, this paper finds an equity demand for conditional conservatism in state-controlled firms and examine some important firm-level variables. However, what is the impact of the findings upon capital market and firms? The papers should identify clearly the implications for research, practice and/or society.

Thanks for this important suggestion which can substantially improve the paper. In the revised version we add the following paragraph:

This study suggests several implications to researchers, investors and regulators on state-controlled firms and capital markets. The findings add to the literature on agency conflicts in firms with concentrated ownership (Claessens et al., 2000). The conservatism demanded from equity investors can serve as a means to contain management's opportunistic behavior in state-controlled firms. In the evaluation of state-controlled firms, especially those with low or zero levels of debt, attention should be paid to how timely accounting income responds to bad news. Institutional reforms in the capital markets should encourage the active participation of investors, the demand for conditional conservatism from equity investors and the protection of the interest of minority shareholders. Also as agency cost control mechanisms are costly (Easterbrook 1984), the corporate governance mechanism at the firm level can be designed to take into account the possible substituting effects between agency control mechanisms. For example, recently the Chinese equity market regulator encouraged listed firms to pay "reasonable" levels of dividends and stated that they would take tough measures against firms that do not pay cash dividends in spite of being able to do so. For some firms, such as those in the beginning or growth stage of their life cycle where reinvestment is important, the cost of dividend payments can be prohibitive. Therefore as an alternative agency control mechanism conditional accounting conservatism could serve as an effective alternative to dividend payments. 